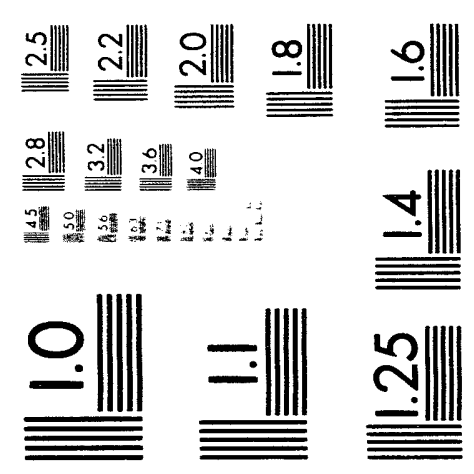



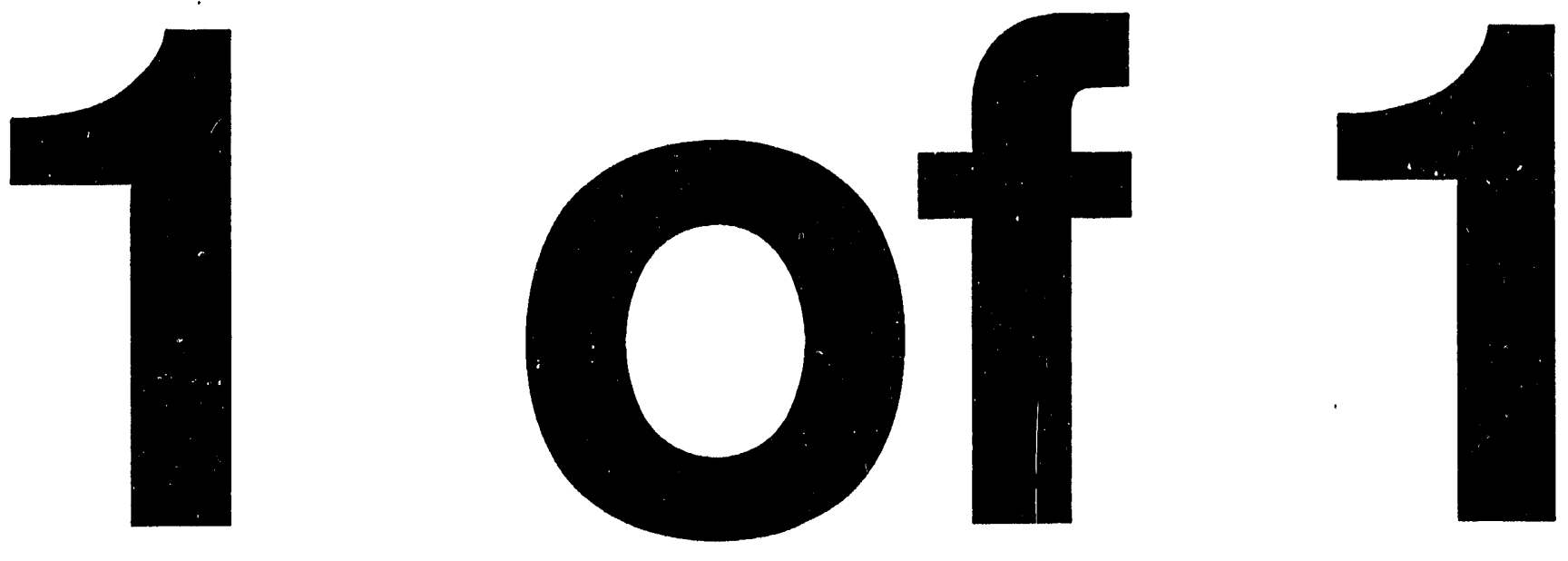


\title{
Why Russia is Not a State
}

\author{
Jessica E. Stern
}

August 16, 1993

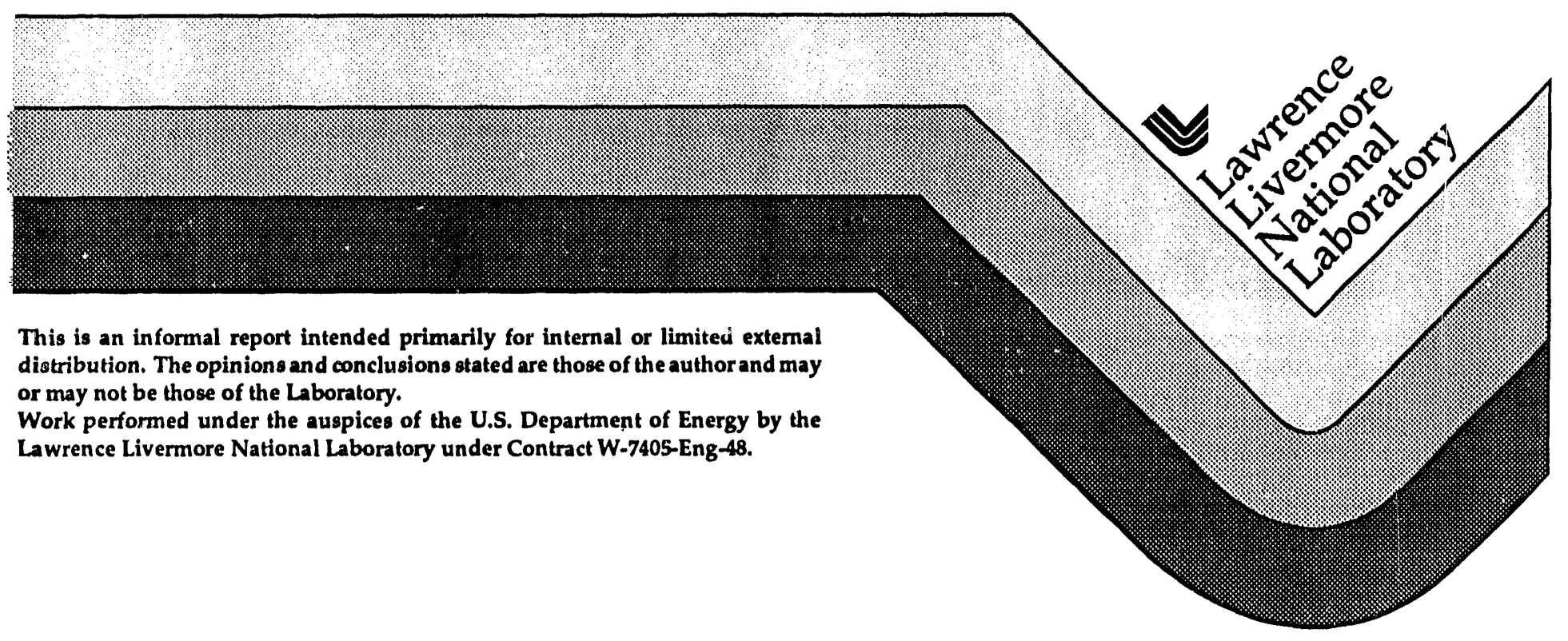

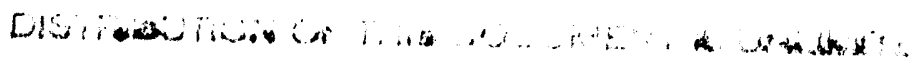




\section{DISCLAIMER}

This document was prepared as an account of work sponsored by an agency of the United States Government. Neither the United States Government nor the University of California nor any of their employees, makes any warranty, express or implied, or assumes any legal liability or responsibility for the accuracy, completeness, or usefulness of any information, apparatus, product, or process disclosed, or represents that its use would not infringe privately owned rights. Reference herein to an y specific commercial products, process, or service by trade name, trademark, manufacturer, or otherwise, does not necessarily constitute or imply its endorsement, recommendation, or fa voring by the United States Government or the University of California. The views and opinions of authors expressed herein do not necessarily state or reflect those of the United States Government or the University of California, and shall not be used for advertising or product endorsement purposes.

This report has been reproduced directly from the best available copy.

A vailable to DOE and DOE contractors from the Office of Scientific and Technical Information P.O. Box 62, Oak Ridge, TN 37831

Prices available from (615) 576-8401, FTS 626.8401

A vailable to the public from the

National Technical Information Service

U.S. Department of Commerce

5285 Port Royal Rd.

Springfield, VA 22161 


\title{
Why Russia is Not a State
}

\author{
Jessica Eve Stern \\ Lawrence Livermore National Laboratory \\ PO Box 808 L205 \\ Livermore, CA 94551 \\ Phone: 5104227071 \\ Fax: 5104234077 \\ internet: jstern@llnl.gov \\ 9/10/93
}

This research was supported by Lawrence Livermore National Laboratory. The views expressed herein are those of the author and not necessarily those of the U.S. government.

I would like to thank Glenn Chafetz, Paul Chrzanowski, Jerry Dzakowic, Paul Goble, Peter Lavoy, Amy Sands, and David Wolff for helpful comments. 


\section{Why Russia Is Not A State}

Moscow's deteriorating relationship with former Soviet republics has been widely noted in the press. Less well known is that the process that led to the break-up of the Soviet Union is continuing within the Russian Federation itself. The most significant threats to the security of the Russian state stem from within the Russian Federation. Deputy Prime Minister Boris Fedorov recently conceded that he is more worried about separatist Tatarstan than he is about Ukraine, despite Ukraine's reluctance to relinquish the former Soviet nuclear weapons on its soil.'

This article makes two principal points. First, I argue that the Russian federation has never been a state and is not sustainable as a state. Four centrifugal indicators are presented to support this claim: ethnic divisiveness; uncertainty about the legitimacy of Russia's current borders; competing claims for legitimacy on the part of federal and regional leaders; and army units' unpredictable allegiances.

Second, I argue that Soviet policies intended to facilitate central control of the periphery had the perverse effect of creating ethnic identity and demands for national autonomy where, in many cases, they did not exist prior to the Communist regime. The establishment of a federal state based on ethnic divisions gave ethnic groups the expectation and, in some cases the administrative infrastructure, of national statehood. Marxist-Leninist theory holds that ethnic distinctions will eventually lose their political significance and that nationalist sentiments will fade away. Instead, the late 20th century has witnessed the fragmentation of the Soviet empire into its constituent, ethnically-defined parts. Unless Yeltsin and his successors find the precise balance between indulging and disciplining 
separatist regions, this fragmentation process will continue within the Russian Federation itself.

The Russian government is increasingly unable to meet its obligations as a sovereign power. Deputy Prime Minister Fedorov recently admitted that the government is failing in its public duty to protect citizens and their currency, ${ }^{2}$ and that he worries about Moscow's ability to maintain macroeconomic control of Russia. ${ }^{3}$ Russians are increasingly conducting business in dollars and in the Far East, in Chinese yuan. ${ }^{4}$ Russian statistics report that the crime rate has nearly doubled since 1985 . $^{5}$ The armed forces are beset by conscription problems and lack of funds. ${ }^{6}$ There is no longer a clear outside threat against which Russia must defend its citizens; and the internal threats to Russia's integrity are proving increasingly difficult to overcome. Russia's new military doctrine reflects concerns about both external and internal threats to Russian Federation (RF) security. ${ }^{7}$

Changing political and economic circumstances have made nationalism a useful political tool in Russia just as it was at the time of the Revolution. Ethnic strife is rippling below the surface in some areas, such as in Buryatia. Other republics are engaged in open internecine conflict. Ingush are demanding to reclaim territory Stalin took from them in North Ossetia. North and South Ossetians are agitating for an "Ossetian Republic" that would encompass the South Ossetian autonomous republic, now part of Georgia. Kabardins and Balkars are trying to split into two autonomous republics.

Intelligence analysts and policy makers should pay closer attention to Russia's potential fragmentation for three reasons: nuclear facilities are located in some of the most volatile regions; army units show greater allegiance to the regions than to the center in some areas; and the possibility of accidents at nuclear facilities is increasing. If former governor of Sakhalin Valentin Fedorov's threat to revive the 1920s Far Eastern Republic were carried out, for example, that republic could be the third largest nuclear power in the 
world. ${ }^{8}$ Political fragmentation of the RF could also loosen control over sensitive exports and increase the risk of terrorist acquisition of fissile materials.

Following the introduction, part one briefly reviews the concepts of state, nation, and nationalism and the roles they play in Russia. Criteria for state-hood are discussed. Part two lists the main ethnic groups in Russia and considers the roots of ethnic nationalism in the Russian Federation. Part three discusses confusion over the legitimacy of the physical, economic, and political boundaries of the Russian Federation. Part four discusses political disarray in the center and in the regions and the lack of unity among order-enforcing entities. The Volga-Ural region--where there is a large concentration of nuclear weapons and facilities, and which is especially volatile politically--is discussed in somewhat more detail. Part five argues that these factors taken together call into question Russia's identity as a state.

I conclude that Russia remains a multi-ethnic empire in which the rule of law is still not supreme. Under Communist rule, the KGB and the party were the order-enforcing entities that defined the state; the constitution and the law were niceties to which leaders paid heed only when it served their interests. Tyranny teaches disdain for law; but democracy cannot exist without respect for it. If there is one attribute of homo Sovieticus that appears truly to have taken root in Russia, it is scorn for the rule of law. Under postCommunist rule, the KGB and the party no longer serve their traditional order-enforcing functions, and disdain for the law has not been unlearned overnight. In post-communist Russia, chaos has replaced order; license has replaced terror. Order-enforcing entities are eviscerated or in conflict. Neither economic shock therapy nor G7 funds can help; Russia will not be a state until new unifying institutions are created--whether democratic or authoritarian.

\section{PART 1: CONCEPTS OF STATE, NATION, AND NATIONALISM}


Political philosophers have wrestled with the ideas of the state and political authority for centuries. The philosophy of the enlightenment held that the universe was governed by an unvarying law of Nature which is intelligible to every person of reason. Societies formed on the basis of natural law would flourish with little intervention. The sole function of the state was to preserve and guarantee the natural rights of persons and to settle disputes that might arise. ${ }^{9}$

Hobbes, in contrast, believed that people are by nature selfish and destructive; a state was necessary "to defend them [citizens] from the invasion of foreigners, and the injuries of one another, and thereby to secure them in such sort, as that by their own industry..they may nourish themselves and live contentedly..."10

Later attempts to define the state have built upon Hobbes' ideal type, focusing on three interrelated concepts: power--in the sense that the state can defend its interests abroad; ${ }^{\prime \prime}$ legitimacy--in the sense that the state commands the loyalty of its citizens; ${ }^{12}$ and order--in the sense that the state is able to protect citizens in their person and property.

A vast literature considers the relationship between power and the state. Georg Simmel, for example, concludes that war was crucial to the development of the modern state. ${ }^{13}$ When the threat of war recedes, states' internal cohesion deteriorates, according to this view. The implication of the theory is that the collapse of external threats coincident with the end of the Cold War may be hazardous to the continuing viability of states, particularly for the superpowers. ${ }^{14}$

Max Weber defines the state in terms of its ability to promote order: the state is that entity in society that claims a monopoly on the legitimate use of physical force. ${ }^{15}$ Ernest Gellner refines Max Weber's definition of the state as the institution or set of institutions "specifically concerned with the enforcement of order."16 
The distinguishing feature of the modern state is its success in resolving the trade-off between loyalty and power, in Robert Gilpin's view. ${ }^{17}$ States amass power and command citizens' loyalty--some by threatening violence or by building walls to keep citizens inside; others (more successfully) by creating what Macchiavelli called a "civic religion" or civic nationalism (discussed below). ${ }^{18}$ Most importantly, there is no authority superior to the state and no morality binding upon it; the state, at least in its ideal form, is the most powerful institution within its physical boundaries. ${ }^{19}$

The test of state-hood cannot be whether all citizens are loyal to the sovereign or feel safe from violence to their person and property. No modern state would meet this test; the question must be one of degree. Instead we will ask whether the Russian government is the most authoritative order-creating entity on the territory of the RF; whether citizens on average display more loyalty to Russia than to their oblast or republic or ethnic group; and whether the Russian government is the most powerful institution on the territory it controls. The remainder of this article considers these questions. It is necessary to define a few more terms, however, before turning to these questions.

A nation is not necessarily the same thing as a state. ${ }^{20}$ Two people are of the same nation if and only if they see themselves as such, whereas whether they are citizens of the same state can be empirically verified. ${ }^{21}$ Those who differentiate between nations and states tend to define nations in terms of culture and states in terms of government. ${ }^{22}$ Stalin, for example, who began his S defined a nation as an "historically constituted, stable community of people, formed on the basis of a common language, territory, economic life, and psychological make-up manifested in a common culture. ${ }^{.23}$

The distinction between nation and state is at the heart of the problem of nationalism and indeed, at the heart of Russia's problem today: ethnic nationalism often arises when 
members of a particular ethnic group believe themselves to be mistreated by the state. ${ }^{24}$ Such feelings may give rise to the desire for ethnic autonomy or national independence or, in the extreme case, competing claims for political legitimacy among federal and local ethnic leaders. Ernst Haas explains, "Nationalism can hold a society together while people are being buffeted by the strains of modernization... [but it] can take two forms: people under stress can seek to resolve it [the stress] by identifying with the existing state, but they can also look for help by seceding from it." 25

In the Soviet Union, ethnic consciousness was intensified by deliberate policies, including conflation of ethnic and political divisions in the federal structure of the state (both at the union and republic level); by intermittent promotion of national cultures and languages; by preferential treatment of ethnic minorities within their own republics-including ethnic quotas in regional administrations and in higher education; by deportation of entire ethnic groups; and by the practice of identifying citizens by ethnic group on internal passports. These policies are discussed in more detail in the next section. Heightened ethnic awareness, coupled with the wide-spread perception that Moscow took advantage of the non-Russian areas of the RF and gravely mistreated non-Russian nationalities, has created a situation ripe for ethnic conflict.

It is also useful to distinguish between ethnic nationalism and civic nationalism. Civic nationalism, which is based on law and the idea of equal rights for all citizens within a given territory, can exist only (but not necessarily) in well functioning democracies. ${ }^{26}$ Scholars describe this first type of nationalism as characteristic of Western democracies. Ethnic nationalism, characteristic of Eastern Europe, is based on common culture -- defined in terms of race, language, tradition or religion. Ethnic nationalism tends to flourish when state institutions fail, which some scholars claim explains the rise of ethnic nationalism in post-Soviet Russia and throughout the post-Communist world. ${ }^{27}$ 
Ethnic nationalism may also be kindled by democratic reforms, especially if those reforms do not include protection of equal rights for all ethnic groups. Ethnic nationalism and democracy are "intimately, if not symbiotically, linked," David Welsh claims. "If democracy means, "the people shall rule," then who are the people?... Thus is opened the way to invidious questions about the status and rights of particular categories of people."28

\section{PART 2: THE RISE OF ETHNIC NATIONALISM IN RUSSIA}

\section{Ethnic Groups}

Twenty-five million ethnic Russians live in former Soviet republics outside of the Russian Federation. Thirty million non-ethnic Russians (comprising over 100 ethnic groups) live within the Russian federation out of a total population of 150 million. Of these, Tatars are the most numerous, followed by Ukrainians, Chuvash, Bashkirs, Belarussians, Mordovans, and Chechens.

The Russian Federation is comprised of forty-nine administratively defined oblasts (provinces) and six similarly defined krais (territories), twenty-one ethnic republics, ten ethnic okrugs (areas), one ethno-religiously defined autonomous oblast, and two citysubjects. Of the 89 "subjects" of the RF, the twenty-one autonomous republics pose the gravest threat to the integrity of the RF by virtue of their escalating demands for economic and political autonomy. They are peopled by Finno-Ugric (Karelian, Komi, Udmurt, Mari, Mordvin); Caucasian (Adygey, Chechen, Cherkess, Dagestani, Ingush, Karbardin); Mongolian (Kalmuk, Buryat); Turkic (Altay, Bashkir, Balkar, Chuvash, Karachay, Khakass, Tatar, Tuvan, Yakut) and Iranian (Ossetian) peoples, Four religions are represented among them: the Finno-Ugric ethnic groups are a mix of Eastern Orthodox and Shamanist; the Caucasian and Turkic groups are predominantly Muslim; ${ }^{29}$ the N. Ossetians are Eastern 
Orthodox; and Tuvans and the Mongolian group are predominantly Buddhist. Those ethnic groups that profess Christianity tend to be the most assimilated in Russia. ${ }^{30}$

\section{The Causes of Ethnic Nationalism in Russia}

Recently there has been a great deal of debate about the rise of nationalism in Eastern Europe. Pierre Hassner argues that states are capable of tolerating ethnic diversity if they display one or more of the following characteristics: a strong central government, a common ideological bond, or a tradition of respect for individual rights. All tinree are lacking in post-communist Russia, however, paving the way for ethnic conflict. ${ }^{31}$

Jack Snyder argues that the prevailing view that ethnic nationalism will emerge in post-Soviet Russia is too pessimistic. ${ }^{32}$ He finds that civic nationalism suits Yeltsin's strategies for unifying a multiethnic society and for transition to a free market economy. ${ }^{33}$ But Snyder fails to note that ethnic nationalism suits the strategy of republican leaders (leaders of the autonomous republics of the Russian Federation), who are fanning the flames of ethnic nationalism with at least three objectives in mind: to solidify regional political support; to push for greater economic and political autonomy; and to deflect disappointment with the results of economic reform back to Moscow. ${ }^{34}$ Some republican leaders' true motivation for inciting ethnic unrest may have more to do with a desire to enhance their own personal power and the republics' share of resource revenues. But if republican leaders are using nationalist propaganda for their own objectives, they are only following a hallowed tradition of power-politics, and a common method of creating political legitimacy.

Contrary to popular conception, ancient, ingrained animosity is not the motivating force behind ethnic nationalism in Russia. ${ }^{35}$ Even in the Northern Caucasus, an area rife with ethnic tensions today, national consciousness is largely a 20 th century phenomenon. Prior to Communist rule, the ethnic groups of the Northern Caucasus saw themselves first 
as members of clans, and secondarily as members of a huge ethnic society of North Caucasian peoples. ${ }^{36}$ Two Soviet policies were critical to the development of national consciousness in the region: the 1921-22 creation of ethnically defined republics, and Stalin's 1944 deportation of the entire populations of the Karachay, Ingush, Balkar and Chechen national groups. Similarly, national consciousness among indigenous peoples of Siberia did not exist prior to the Soviet regime. ${ }^{37}$ The government's essential role in politicizing ethnic groups is not unique to Russia. Scholars note the decisive role of the state in politicizing ethnicity among Muslim Chinese and among many of the national groups in India. ${ }^{38}$

Ethnic tensions in Russia are largely attributable to Soviet nationalities policies implemented in the first three decades of Communist rule. Lenin astutely recognized the latent power of ethnic consciousness, and cynically used nationalist sentiment to attract the support of ethnic groups suppressed by Tsarist rule. ${ }^{39}$ The right of nations to selfdetermination was the cornerstone of the Bolshevik program between the end of the first World War and $1917 .^{40}$ Lenin not only opposed forcing non-ethnic Russians to adopt the Russian language but, in contrast to Bukharin, persistently defended nations' right to secede. $^{41}$ When Ukraine (in the spirit of self-determination) refused to allow Red Army troops on its soil in 1918, Lenin's Commissar of Nationalities, Joseph Stalin, advocated a reinterpretation of the right of national self-determination: "The principle of selfdetermination ought to be used as a means in the struggle for socialism and it ought to be subordinated to the principles of socialism." Moreover, the principle applied only to the "toilers" and not to the bourgeoisie. ${ }^{42}$

Lenin and Stalin implemented a number of policies to increase regions' dependence on the center, weaken ethnic power blocs, and crush secessionist aspirations. Five of these policies are highlighted here; others are considered elsewhere in the literature. ${ }^{43}$ All five 
strategies have had the unintended effect of further politicizing ethnic groups. The first strategy was to organize the Soviet Union as a confederation of fifteen union republics, most of which were dominated by a single ethnic group. ${ }^{44}$ (I will use the term "union republics" to refer to the fifteen former Soviet republics. The term "republics" will refer to autonomous republics within the Russian Federation.) The union republics were granted a semblance of autonomy including, as mentioned above, the right to secede--a right that was never expected to be taken seriously. All real power in this Soviet form of federalism was held by the center--by the Communist party, the KGB, and the planners of the command economy. When the party began to weaken in 1990 , the union republics used the paper autonomy Lenin gave them to demand more independence and, ultimately, to secede.

Lenin professed the desire that Communism correct and even make up for Tsarist policies of oppression of non-Russian nationalities. In 1922 Lenin claimed,

A distinction must necessarily be made between the nationalism of an oppressor nation and that of an oppressed nation, the nationalism of a big nation and a small nation...[W]e nationalists of a big nation, have nearly always been guilty, in historical practice, of an infinite number of causes of violence... That is why internationalism on the part of oppressors or 'great' nations...must consist not only in the observance of the formal equality of nations but even in an inequality of the oppressor nation. ${ }^{45}$

Critics argue that the Lenin's policies of granting the appearance of autonomy to national groups (including "nativization" policies, which granted special privileges to minorities and promoted regional cultures and languages) were devised to appease separatism, rather than to make up for the sins of the "oppressor nation." 46 Whatever Lenin's true motivations, however, Russian chauvinism was quickly revived under Stalin's rule in the 1930s. The federal state structure was preserved, but support for nationalities and regional autonomy were drastically reduced. ${ }^{47}$

Ten out of the fifteen union republics were sub-divided further into regions that also enjoyed the appearance of some sovereignty, although significantly less than that of the 
union republics. Four of these union republics wer: divided in part along ethnic lines. The creation of autonomous republics (ethnic territories within the Union republics), like the creation of the Soviet republics, was intended as an instrument of consolidation to crush separatism. $^{48}$ The policy turned out to have many serious drawbacks. Minorities that were not granted their own autonomous republics were resentful. Quotas that favored titular nationalities in republican adrninistrations resulted in the rise of "parasitic attitudes and the diminishing prestige of productive work." ${ }^{49}$ National groups living in ministates with their own political infrastructures have been the most effective lobbyists for regional autonomy and, in the case of Tatarstan and Chechenya, independence from the RF. Not surprisingly, in two of the four union republics with ethnic subdivisions, Azerbaijan and Georgia, civil war has broken out. In a third, Russia, several ethnic groups are in conflict, as this article makes clear. The fourth former Soviet republic that was divided partly on ethnic grounds is Uzbekistan.

Most importantly, the tradition of special privileges for autonomous ethnic republics has greatly complicated the post-Soviet regime's attempts to create a law-based state in Russia. The autonomous republics on average have fewer resources, less industrial wealth, and contribute far less in taxes than the krais and oblasts. ${ }^{50}$ But Soviet policies led the republics to expect to be treated better than the more populous Russian regions. ${ }^{51}$ Even in post-Communist Russia, autonomous republics continue to enjoy far more political and economic autonomy than the ethnic-Russian regions. Krai and oblast leaders' perception that republics are getting an unfair advantage was the major impediment to swift completion of a new constitution during the 1993 Constituent Assembly. ${ }^{52}$

Stalin's second strategy was arbitrarily to combine two or more unrelated ethnic groups within a single ethnic territory--presumably to weaken secessionist aspirations. For example, in what became Karachay-Cherkessia, Stalin combined Caucasians (Cherkess) and 
Turkic (Karachay) peoples whose languages are mutually unintelligible. ${ }^{53}$ A similai policy resulted in a combined Kabardino-Balkarian republic, which inter-ethnic strife is now threatening to dissolve. ${ }^{54}$

Stalin's third strategy was to divide ethnic groups to weaken power blocs with imperiously drawn, artificial borders. In 1937 Stalin created three separate ethnic entities out of the former Mongolian Buryat Autonomous Republic: the republic of Buryatia; the Aga Buryat area within Chita oblast, which contained a significant portion of the former Buryat-Mongolia's cattle and farm areas; and the Ust' Orda area located in Irkutsk oblast, which was rich in lead. ${ }^{55}$ Buryats have been increasingly vocal in their demand that these three parts be reunited. On 3 June 1993, the Buryat parliament declared Stalin's 1937 decision to split up the republic to be unconstitutional. ${ }^{56}$ One Russian official described the situation in Buryatia as potentially as explosive as Nagorno-Karabakh, where Armenians have been agitating for independence from Azerbaijan.

The fourth strategy was deportation. Seven ethnic groups were deported from their native territories en masse: the Volga Germans; the Kalmyks; the Crimean Tatars; and the Chechens, Ingush, Karachai, and Balkars of the Northern Caucasus. Conquest estimates that the total number of people despatched into exile was approximately $1,250,000 .^{57}$ Many thousands of deportees perished en route.

Khrushchev's 1956 edict to allow most of the deported nationalities to return created new problems, which were aggravated by the Law on the Rehabilitation of the Repressed peoples passed by the Supreme Soviet in 1991. This law allowed the deported nationalities to claim their former territories. The conflict over land formerly held by Ingush on the territory of $\mathrm{N}$. Ossetia has become especially fierce. ${ }^{58}$ Russia's apparent pro-Ossetian stance resulted in extraordinarily low support for Yeltsin in Ingushetia in the 25 April 1993 
referendum. ${ }^{59}$ Similar problems have arisen for other deported nationalities, although no other conflict is as violent. ${ }^{60}$

The fifth strategy was to encourage or in some cases to enforce Russian migration to the periphery, not only to the former Soviet republics, but also to regions within the Russian federation. The Soviet government held out the promise of significantly higher salaries as well as tax advantages for citizens willing to relocate, particularly to the Far East. $^{61}$

In summary, the creation of a federal state based on ethnic divisions and protection of national groups' right of self-determination were intended as temporary measures to facilitate central control and to crush separatist aspirations. These and other policies described above have had unintended, surprisingly divisive consequences during the last five years--both in the Soviet Union and in the Russian republic. Interestingly, ethnic problems are most acute in those former Soviet republics that were subdivided in part along ethnic lines, including Azerbaijan, Georgia, and Russia.

\section{PART 3: BORDERS}

Because Russia has no natural boundaries in the West or the South, beliefs about the legitimacy of Russia's borders play an exaggerated role. Paul Goble explains, "Because Russia became an empire before the Russians consolidated as a nation, the psychological limits of the state and of Russian identity have always been problematic. Russia has always been a pre-modern empire with a center and a periphery...."62

The Russian state has never existed within its current borders. Late imperial Russia and the Soviet Union both encompassed a significantly larger territory. Russia originated in what is now Ukraine. Kievan Rus lasted from the 9th through the 13th centuries, when it was conquered by the Tatars, who ruled most of European Russia for the 250 year "Tatar Yoke." ${ }^{163}$ During the Kievan Rus period, Russia developed a uniform religion (Eastern 
Orthodoxy) and a common written language and literature. The idea of a Russia separate from the two other Eastern Slavic republics (Ukraine and Belarus) is galling to ethnic Russians. ${ }^{64}$

The next Russian state, which was centered on Moscow, expanded in three directions. ${ }^{65}$ Finnish tribes in what is now Northern Russia were absorbed by Kievan Rus in the 12th century, and by Muscovite Russia in the 16th century. Expansion into the predominantly Muslim South took over three centuries. Ivan the Terrible conquered Islamic Khanates in the Volga Region in the mid-16th century. Many of the regions on and between the Black and Caspian Seas were annexed in the 18th and early 19th century, but Chechenya and Circassia in the Northern Caucasus were not defeated until the late 19th century. ${ }^{66}$ Siberia was conquered beginning in the late 16 th century, but colonization did not really begin until the late 19 th century, largely by convicts.

The Eastern Slavic states of Ukraine and Belarus are arguably more Russian than much of what is now the RF: most of the territory east of Suzdal and south of Kiev was acquired by conquest in later centuries. Ethnic Russians consider themselves to be closer psychologically and culturally (as well as linguistically and geographically) even to the Western Slavs (Czechs and Poles) and Southern Slavs (Serbs, Croats, and Bulgarians) than to the aboriginal peoples of Siberia and the Caucasus.

In a widely distributed brochure published in two Russian newspapers shortly after the RSFSR declared sovereignty, Nobel Laureate Aleksandr Solzhenitsyn recommended the formation of a Pan-Russian Union, which would include Northern Kazakhstan (heavily populated by Russians); and those parts of the Ukraine and Belarus that chose to remain with their Russian brethren. ${ }^{67}$ This proposal was in keeping with the 19th century Slavophile movement, which Solzhenitsyn and other modern Russian nationalists are trying to revive. Non-Russian areas of the RF with external borders (such as Buryatia, Tuva, and 
the Northern Caucasus) would be free to secede from the RF if the majority of the republic so chose. Those non-ethnic Russian republics with no borders external to the RF, such as Tatarstan, would have to remain part of Russia, but their economic, religious, and ethnic needs would have to receive utmost attention, Solzhenitsyn argued. Since then, a number of Russian nationalist parties developed proposals for a Russian Federation with redrawn borders, many of which include Ukraine or parts of it. ${ }^{68}$

A poll commissioned by Yeltsin's government in 1993 indicates that many Russians are dissatisfied with Russia's current borders, and moreover, that ethnic Russians and nonethnic Russian citizens of Russia have conflicting views about where the borders should be. Thirty-nine percent of those polled in one ethnic-Russian region claimed that the Russian state should encompass the whole territory of the former Soviet Union. In the non-Russian ethnic republics, an average of forty percent of those polled claimed that either Russia's present borders were too big, or that the question was too difficult to answer. ${ }^{69}$

Borders are increasingly porous to trade, sometimes outside of Moscow's control. Economic associations and free-trade zones are forming both among Russian Federation regions and between the regions and other countries. There are at least eight separate economic associations to which RF subjects belong: North West Association; Central Russian Association of oblasts and cities; Central Black Earth Region Association of oblasts; Greater Volga Association; Greater Ural Association: Siberian Accord; Far Eastern Economic Association; and the Association of Autonomous Okrugs. ${ }^{70}$

Three factors make trade between the Russian Far East and its neighbors especially attractive: the enormous distance between Moscow and Eastern Siberia, the booming economies of the Pacific Rim region, and resource complementarities. Russia has a comparative economic advantage in wood, minerals, oil, and other natural resources, while Japan and South Korea excel in technology. One proposed project to process raw materials 
will draw on North Korean and Chinese labor, South Korean and Japanese technologies, and Russian natural resources. ${ }^{71}$ Russian fishing vessels are selling fish directly to Japan, rather than arranging trade through official channels. ${ }^{72}$ Cross border trade is also flourishing between Karelia and Finland and among countries near the Black and Caspian seas. $^{73}$

The regions' economic interests do not necessarily coincide with Moscow's political interests, however. Yeltsin's government opposed a Vladivostok initiative jointly to develop heavy industry with Pacific Rim countries, and to create a free economic zone. Moltz attributes Moscow's opposition to this project to its fear that transborder regional integration may lead to national disintegration. ${ }^{74}$

The most alarming aspect of Moscow's declining control over regional exports is the possibility that nuclear materials or expertise would be sold, for example, to North Korea or Iran. So far, none of the numerous allegations of nuclear smuggling has been publicly confirmed by a Western government agency. ${ }^{75}$ But there appear to have been several cases in which government officials were able to impede what might otherwise have been a dangerous situation. In December 1992, for example, the Russian government caught 36 nuclear scientists on a plane bound for North Korea. ${ }^{76}$ Disgruntled nuclear weapons scientists's threatened strikes at the design laboratories Arzamas 16 and Chelyabinsk 70 is yet another indication of the kind of dangers likely to emerge if Moscow declines to keep take the scientists' needs more seriously. ${ }^{77}$

\section{PAR'T 4: WEAKENED CENTRAL CONTROL AND LACK OF ORDER}

Galina Starovoiteva, former advisor to Boris Yeltsin on nationality issues, claims that "the unity of any state is dependent on two basic factors: an integrated economic system (market or command) and a uniform ideological system, whether political, nationalist, or religious." Both, she claims, were destroyed with the Soviet Union. ${ }^{78}$ The KGB and the 
party were the principal unifying forces of the Communist regime; no other unifying force has taken their place. This, together with the incessant fighting between the executive and legislative branches has created not only a power vacuum, but also a sort of "glue vacuum." Very little is left to hold the country together.

In a society characterized by order, citizens have the following expectations: property relationships will be stable, promises will be kept, and individuals will be secure against violence. ${ }^{79}$ Instead, the crime rate in Russia is widely perceived to be soaring. ${ }^{80}$ This, together with the Central Bank's sudden announcement in July 1993 that it was withdrawing from circulation all rubles printed before that year, may have dealt a fatal blow to Russian citizens' faith in their currency and their confidence in the government's ahility to protect private property. ${ }^{81}$

Some order-creating entities were destroyed with the end of the Communist regime. Those that still exist are often in conflict. Federal bureaucracies are now competing, rather than cooperating, particularly in setting economic policy. Failure to develop a coherent economic policy is frightening off investors. ${ }^{82}$ Foreign firms demand, at a minimum, that the government know the law and guarantee the law's continuity. Multilateral lending agencies demand that governments account for assistance provided. ${ }^{83}$ The Russian government has been unable to provide these assurances, which has adversely affected its ability to attract investors and foreign assistance. Strife between the young reformers hired by Yegor Gaidar, and the older conservatives brought on by Victor Chernomyrdin, has played out in a series of disastrous economic policies approved in July 1993 that would lead, if implemented, to a budget deficit equal to $25 \%$ of Russia's GDP. ${ }^{\text {B4 }}$ U.S. government officials also lament the lack of a coherent policy on implementing export controls, and the difficultly of determining the responsible agencies. It is not just that agencies don't agree about how to interpret policies, but that the chain of command is unclear. 
One prescient analyst noted shortly after the failed coup in 1991, "Modern states rest less on palpable things, like building and tanks, than on habits of obedience and accountability that link higher and lower of ficials in a government organized by laws and rules, and on the political culture that supports these laws and rules.... What the coup made manifest was a growing disintegration of the state." ${ }^{\text {8s }}$ The conflict among governing bodies-- especially between the executive and parliamentary branches--has created a climate of chaos, which is now being mirrored in some of the regions. Chechenya's radical nationalist president, Dudaev, ousted the parliament in April 1993; that republic is now close to civil war. ${ }^{86}$ Kalmykia's reformist president llyumzhinov disbanded the parliament and vowed to replace it with a much smaller, more "professional" body. ${ }^{87}$ Yeltsin did not oppose Ilyumzhinov's actions, although they were in clear violation of the RF constitution. ${ }^{88}$ In Mordova, the conservative parliament ousted President Guslyannikov, and ignored Yeltsin's demands that the president be reinstated. ${ }^{89}$ The main issue at stake both in Mordova and Kalmykia is the pace of economic reform: both presidents favor quicker reforms, while the Parliaments are more conservative. The disregard of RF laws in all three republics illustrates the confusion over which law takes precedence: that of the center or that of the constituent republics.

Perhaps most importantly, chaos in Moscow has allowed regional leaders and nationalist organizations to wrest more power for themselves. At least twenty constitutions exist in the RF today: the amended 1977 Russian constitution, which is still the only federal constitution in force; Yeltsin's July 1993 constitution, the fate of which is not yet determined; and at least eighteen draft constitutions ready for ratification by the parliaments of the republics that signed the Federal Treaty of March $1992 .{ }^{40}$ The leaders of a number of republics made clear at parliamentary hearings in March 1993 that they regarded the Federal Treaty as a step toward confederal relations with Moscow, but they believed that a 
"civilized divorce" will be the final result. ${ }^{91}$ The constitutions of at least nine republics-including Bashkortostan, Buryatia, Chechenya, Kalmykia, Karelia, Mordova, Sakha, Tatarstan, and Tuva--declare primacy of local laws over federal ones. The regions have adopted 14,000 laws that directly contradict federal legislation, none of which has been repealed. ${ }^{92}$ Chechenya has effectively seceded from the Russian Federation. Militant nationalist organizations in several republics have created parallel parliaments or national assemblies. $^{93}$ Two republics--North Ossetia and Ingushetia--unilaterally repealed the central government's decree on disarming unlawful armed groups. ${ }^{94}$ Five republics-Tatarstan, Bashkortostan, Sakha, Chechenya, and Karelia--have demanded the right to float their own currencies and to collect their own taxes. ${ }^{95}$ Krasnoyarsk Krai introduced its own currency in July 1992. ${ }^{96}$

A number of republics were able to extract important concessions from Moscow during the Constitutional Assembly, Tatarstan foremost among them. Prime Minister Chernomyrdin granted permission for weapons producers in Tatarstan to export arms outside of Moscow's purview. Analysts worry that the prospects for illegal proliferation of weapons and technologies may increase, especially because Tatarstan already has iridependent control of its exports. ${ }^{97}$

There are now approximately 150 nationality based political organizations in Russia, a Ministry of Internal Affairs official testified in March 1993, some of which are engaged in illegal activities including inciting ethnic strife or establishing their own militia. Nationalist groups in Tatarstan and Bashkortostan have already formed army units. The Confederation of the Peoples of the Caucasus has announced its intention to establish its own army and air-force, including antiaircraft defense systems. ${ }^{98}$

There is growing concern also about RF army's loyalty to the center, and about increasing evidence of corruption and drug addiction. "Local authorities are luring away the 
troop commanders and military district commanders, " a Russian analyst claims. "People in the military realize that it isn't from the center that they're getting their apartments, kindergartens, and food. And therefore, if they have to make a choice, they will carry out the orders of the local authorities." 99

In June 1993 Vice President Aleksandr Rutskoi described the army as being in "disastrous" condition, and accused the High Command and officers of corruption. He also accused Yeltsin of being more interested in buying off the military leadership with promotions than with addressing the army's problems. ${ }^{100}$ Although Rutskoi's charges were undoubtedly made, at least in part, for political purposes, reports of corruption and lack of discipline abound in the Russian press.

The next section discusses an especially volatile regions in somewhat more detail: the Volga-Ural region--focusing on the republic of Tatarstan. This regions was selected for two reasons: independence movements are strong, and there are large numbers of nuclear weapons and nuclear facilities located in the area.

\section{Greater Tatarstan region}

Tatarstan and the surrounding region north of Crimea has been part of Russia since 1552, when Ivan the Terrible conquered the Kazan Khanate. Tatar nationalists now refer to the last 441 years as a period of Russian occupation and exploitation by Russian "newcomers." One Tatar nationalist complains, "I would very much like to say that Russia gave more to the Tatar civilization than prostitution and alcohol abuse, but I can't say this." 101 Fauzia Bairamova, the leader of the Tatar nationalist party Ittifak, is demanding the return of all lands held by the Tatars in the 13th-14th centuries, which she describes as half of Russia's territory. Ittifak demands the predominantly ethnic-Russian provinces of Simbirsk, Saratov, Samara, Astrakhan, and Orenburg; plus the Ufa Plateau, the Western slope of the Urals, and the lands of the Siberian Tatars and Sergach Mishars. ${ }^{102}$ 
At the time of the October revolution, Tatar intellectuals and religious conservatives advocated the formation of a pan-Turkic autonomous republic, which would be called Idel Ural (Volga-Ural), comprising Tatar, Mari, Udmurt, Chuvash, and Bashkir lands. ${ }^{103}$ The Soviet state opposed the idea of an Idel Ural republic. Stalin employed his typical divide and rule tactics to sabotage pan-Turkic enthusiasm and to undermine the Idel Ural idea. He created autonomous republics for the six officially recognized nationalities in the region: Bashkirs, Chuvash, Mari, Mordovans, Tatars, and Udmurts. "The majority of the peoples of the Middle Volga actually benefitted as a result of Soviet anti-Tatarism and anti-PanTurkism, " Ron Wixman explains. ${ }^{104}$

Since 1990, Tatarstan has emerged as one of the two most militant republics of the Russian Federation. (The other is Chechenya.) Tatar nationalists objected to presidential elections taking place on their territory in June 1991, claiming that Yeltsin "may become the president of the RF, but he won't be our president." I0s Tatarstan acquired its own coat of arms, flag, and constitution, and has its own diplomatic representation within RF embassies. $^{106}$ Tatarstan has demanded to join the CIS. ${ }^{107}$ Tatarstan did not sign the 1992 Federal Treaty, ${ }^{108}$ and threatened to boycott the June 1993 Constitutional Assembly unless its "special relationship" with the RF was acknowledged. ${ }^{109}$ Less than a quarter of those eligible to vote participated in the April 1993 referendum. ${ }^{110}$ Only radical nationalists support outright secession from the RF, however, at least so far. Tatarstan's President Shaymieyev still supports "gradual implementation of Tatarstan's state sovereignty" while maintaining union with Russia. "I

Fauzia Bayramova, the above mentioned leader of Ittifak, claims that Tatarstan's future is as an "independent state with all its attributes," ruling out "delegating any prerogatives to Russia, not even defense." 112 Ittifak and other nationalist organizations strongly discouraged soldiers from serving in the CIS (now Russian) armed forces outside 
of the Volga-Urals region. Later, the official Tatarstan parliament passed a resolution prohibiting citizens from serving outside of Tatarstan or the Volga-Urals Military District, except for soldiers serving as border guards. ${ }^{113}$ Desertion and evasion of conscription have become widespread throughout the RF, but reports suggest that this is particularly the case in Tatarstan. ${ }^{1 / 4}$ Both the Ittifak Party in Tatarstan and the Bashkir Urals Movement have established their own combat detachments. ${ }^{115}$

There has also been renewed support for the 1920s idea of a Volga-Urals confederation, although which republics and provinces would be part of such a confederation--if it were to come into being--is unclear. For example, the Tatar Milli Mejlis, the protoparliament of Tatarstan, supported the initiative of national movements in Tatarstan, Chuvash and Mari El to create a Confederation of Peoples of the Volga and Ural Regions. $^{116}$ Ittifak proposed uniting all Turkic peoples in a pan-Turkic State, which would have access to the Black and Caspian Seas through redrawn borders. Bashkortostan and Tatarstan officially informed the RF government about a draft agreement to set up a Volga-Ural presidential republic with its own legislature. The capital would be Ufa (capital of Bashkortostan), and it would comprise Tatarstan, Bashkortostan, Komi, Udmurtia and Chuvash. ${ }^{117}$

Tatars are spread throughout the region and elsewhere in the Russian Federation. Of the Tatar population of the countries of the former Soviet Union, only $26.5 \%$ live in Tatarstan. An additional 20\% live in the surrounding republics of Bashkortostan, Chuvash. Mordova and Udmurtia. Tatars comprise only $49 \%$ of the population of Tatarstan; Russians comprise $43 \%$, and the remainder are other Turkic and Finno-Ugric peoples, predominantly Chuvash. Tatars outnumber Bashkirs in Bashkortostan. ${ }^{118}$

Half the Volga republics are populated principally by Turkic peoples (Bashkortostan, Chuvash, Tatarstan) and half are populated by Finno-Ugric animist/shamanists and 
Christians (Mari El, Mordova, Udmurtia). Although historically the other five republics resented Tatar economic and cultural domination, these republics now resent Russian economic domination even more. ${ }^{119}$ One Russian journalist warned that actions taken by the Russian government to weaken the separatist movements could lead to the creation of a "bristling enclave" in the center of the RF, bringing ultraradical Turkic nationalists to power throughout the region. ${ }^{120}$

\section{Security Implications of Tatar Separatism}

To understand why Tatar separatism, and especially the revived Idel Ural movement, are so threatening, one must appreciate the kind of assets that exist in the region. First, nuclear weapons design laboratories, nuclear weapons sites, and many manufacturing facilities related to nuclear weapons are located in the republics and oblasts of the VolgaUrals Region. The renowned weapons laboratory Arzamas 16 is located partly on the territory of Mordova and partly in Nizhny Novgorod, and Chelyabinsk 70 is located in the near by province of Chelyabinsk. ${ }^{121}$ Mobile ICBMs are based in Mari El, Krasnoyarsk, and Perm; silo-based ICBMs are located in Orenburg, Saratov, and Chelyabinsk. ${ }^{122}$ Uranium is enriched in Krasnoyarsk and Sverdlovsk, and reprocessing facilities are located in Chelyabinsk and Krasnoyarsk. ${ }^{123}$ Ballistic missiles or bombers are produced in Samara and Udmurtia. ${ }^{124} 80 \%$ of Mari El's industry is defense-related. ${ }^{125}$ Udmurtia manufactures rockets, communication facilities and accessories for nuclear weapons. Chemical weapons, principally lewisite (a blistering agent) are also stored there. ${ }^{126}$

Second, Tatarstan is at the crossroads of major rail and oil and gas pipe lines which link European Russia with Siberia and the Far East. The Volga River, which runs through the proposed Idel-Ural republic, is an important shipping link.

Third, Tatarstan and Bashkortostan, along with many of the surrounding provinces, are tremendously rich in natural resources and industrial capacity. Although seventy-five 
percent of Russia's oil is found in two autonomous areas in the Tyumen region, most of the remainder is located in these two republics. Bashkortostan has on its territory as much oil as Kuwait. Large coal and copper deposits were recently discovered in Tatarstan. ${ }^{127}$ Tatarstan's GNP exceeds that of Armenia, Estonia, Latvia, Lithuania, Moldova, Tajikistan, and Turkmenistan. Most of Russia's gasoline refining capacity is located in the Volga-Ural region. ${ }^{128}$ Tatarstan produces a significant fraction of Russia's trucking fleet as well as Backfire aircraft. ${ }^{129}$ Samara, a predominantly ethnic-Russian province to which radical Tatar nationalists are now laying claim, produced an astonishing $44.8 \%$ of all machinery and equipment exported by the RF in 1991. Most of Russia's Volga automobile manufacturing capacity is located in Samara, as are a number of military enterprises. ${ }^{130}$ Two out of the three regions that contributed the largest fraction of Russia's convertible currency export earnings in 1991 are located in this region: Samara and Krasnoyarsk (Tyumen, where most of Russia's oil is located, is the third.) ${ }^{131}$

Russians who worry about separatist movements in the region take comfort in the knowledge that a Greater Tatarstan, even one that included the neighboring five independence-minded republics, would have no borders external to Russia and would therefore have difficultly surviving as a separate state. ${ }^{132}$ But this problem could be overcome if one or more of the regions south of Bashkortostan were convinced to join an Idel Ural republic. "People here do not rule out the formation of a Volga-Urals Federation that would include six of the Russian Republic's constituent republics, and even the adjacent provinces," a Russian journalist notes. ${ }^{133}$ As mentioned above, nationalist Tatars are demanding the return to Tatar control of some of the provinces bordering Kazakhstan. Were the official parliament to make such demands, conflict could easily turn violent. The population of the regions south and east of Bashkortostan is predominantly ethnic-Russian and "stable" or at worst "potentially unstable," according to a study of 
investment risks recently published by Commersant. ${ }^{134}$ All with the exception of Samara showed relatively strong support for Yeltsin in the April 1993 referendum. $^{135}$ As is the case throughout the RF, the provinces in general are far wealthier than the republics. Sverdlovsk, for example, paid 95 billion rubles in federal taxes in 1992, and received 30 billion back. Most republics, in contrast, contribute far less than they receive. ${ }^{136}$ If resentment over revenue sharing begins to take on ethnic dimensions, as undoubtedly it will, a more likely result than union is precisely the reverse: ethnic-Russians will begin to leave the Turkic republics, and Turkic minorities now living in the neighboring provinces will migrate to Tatarstan, Chuvash or Bashkortostan. ${ }^{137}$

Increased support for Idel-Ural even in the surrounding provinces cannot be entirely ruled out, however, mainly because of economic incentives. Two economic associations have already been formed in the Volga-Ural region that comprise both ethnic-Russian and non-ethnic Russian regions. ${ }^{138}$ Agitation to form stronger political bonds among regions is not confined to the republics. Several democratic organizations in the Urals proposed to the Russian Federation Parliament in 1992 that a Ural republic be formed, comprising Orenburg, Chelyabinsk, Kurgan and Sverdlovsk oblasts. ${ }^{139}$ Most importantly, Sverdlovsk's July 1993 proclamation that it had changed its name and status to the Ural Republic suggests that economic considerations are beginning to dominate nationalist sentiments as well as allegiance to the center. ${ }^{140}$ If this trend were to continue in other provinces, support for a Volga-Ural confederation may grow. Given the enormous economic and military capacity of the Volga-Ural region, violent conflict would be the likely outcome.

\section{CONCLUSION:}

Russia's legitimacy weakens on numerous fronts. Federal and regional leaders compete for citizens' loyalty. Ethnic tensions rise. Power devolves to the regions. 
Republics' laws conflict with federal ones. Republics set their own foreign and economic policies. No external threat counteracts internal centrifugal tensions. Nor can the center count on the armed forces to hold the regions in check. Manning levels for enlisted men will soon preclude the armed forces's normal functioning, and the allegiance of army units is uncertain. Taken together, these factors suggest that Russia is not sustainable as a single state.

In Soviet Russia, order was maintained--not by the rule of law, which was neither uniform nor consistent--but by tyranny. No order-creating entities have yet appeared to take the place of the Communist Party and the KGB. The existence of competing constitutions, together with the Russian public's acquired disdain for the law, make a lawbased state improbable in the near future. The parliament's sudden decision to remove rubles from circulation in July 1993 dealt a crippling blow to citizens' faith in the ability of the government to protect contracts and to maintain a credible currency. Russia is failing to meet the obligations of a sovereign power.

Ironically, early Soviet policies intended to facilitate central control by crushing ethnic-nationalist aspirations laid the foundation for the break-up of the Soviet Union and the possible break-up of three of the four Soviet republics that contain autonomous ethnic republics: Georgia, Azerbaijan, and Russia. The formation of a federal system based on ethnic subdivisions created the expectation and the political infrastructure of national statehood within those republics. In Russia, intense rivalries over scarce resources--both among ethnic republics and between ethnic and non-ethnic regions--could lead to civil war.

The potential fragmentation of Russia poses far graver threats to world security than did the Soviet Union's demise, but once again intelligence analysts and policy makers ignore the facts. Sovereignty grows weaker in Russia--perhaps it is dying; utter chaos threatens to emerge. Ethnic divisiveness and demands for greater independence are acute in 
areas with vast nuclear arsenals that border Kazakhstan, China, Japan, and the Koreas. We cannot afford to continue to ignore Russia's impending collapse; war and peace are at stake.

The following concrete recommendations--addressed to both U.S. and Russian policy makers--follow from the preceding analysis.

The U.S. government needs to take the potential for Russia to fragment far more seriously. Russian break-up will have profound implications for U.S. relations with Russia's neighbors, including the Pacific Rim and the former Soviet republics. Nationalist movements and regional economies should be tracked. Appropriate responses to the sale or capture of nuclear weapons, facilities or materials, and to the appearance of new nuclear states should be considered.

If and when parts of Russia begin to secede, the U.S. adrninistration should not repeat the mistakes the previous administration made with respect to Ukraine. Clinton should take all fledgling secessionist republics seriously, not just those with nuclear weapons or facilities on their territory.

The fight between Yeltsin and the parliament could easily exacerbate center-periphery tensions with each side in this fight tempted to exploit ethnic cleavages as a source of support against the other. Ratcheting up this conflict risks worsening ethnic tensions; the parliament, after all, represents regional interest. The U.S. should avoid demonizing the parliament.

Redeployment or deactivation of weapons located in politically volatile regions should be considered.

Unless all subjects of the federation are given equal economic and political powers, Yeltsin and his successors' efforts to maintain Russia's integrity will fail. At the same time, Yeltsin faces a difficult challenge. Granting oblasts and krais equal powers to those enjoyed by the republics will infuriate the republics, but allowing non-Russians to maintain greater powers will inflame ethnic tensions. Of these two, the former is nonetheless the better strategy. If powers continue to be granted on the basis of ethnicity, ethnic tensions will tear the RF apart.

Most importantly, Yeltsin should not yield to the temptation to take away rights already granted to republics; the other subjects' rights should be brought up to the level of those enjoyed by republics, not the other way around. When Gorbachev tried to reign in the union republics' newly acquired freedorns, the Soviet Union splintered. Yeltsin should learn from Gorbachev's mistakes. 
1.Ann Sheehy, "Deputy Premier Fedorov on Demands of Republics" RFE-RL Daily Report. 3 June 1993.

2.John Lloyd, "Fyodorov Bares All on Russia's Economic Woes" Financial Times 27 May 1993.

3.Erik Whitlock, "Fedorov on Reform, Economy" RFE-RL Daily Report 8 June 1993.

4.John Lloyd, "Fyodorov Bares All on Russia's Economic Woes" Financial Times 27 May 1993. David Wolff has observed Chinese yuan being used as payment as far West as Lake Baikal. Personal communication with David Wolff, July 1993.

5.Sheila Marnie and Albert Motivans, "Rising Crime Rates: Perceptions and Reality" RFERL Research Report 16 April 1993.

6.Lt. Gen. Vladimir Bondartsev, first deputy chief of the Defense Ministry's organization-mobilization directorate, said on 15 July that by Fall 1993, manning levels for enlisted men would reach one third of the required number, making normal functioning of the army impossible. Stephen Foye, "More on Army's Manpower Problems" RFE-RL Daily Report, 16 July 1993.

7.Russian Defense Minister Pavel Grachev explains, "One cannot forget that on the territory of Russia there live some 20 million inhabitants who profess Islam. If the flames of war are not put out in Tadjikistan, then there are possible dangerous consequences even for Russia, all the more so since aggressive inclinations are appearing in Chechenya." Quoted in John Lepingwell, "Restructuring the Russian Military" RFE-RL. Research Report, 4 June 1993. 8.Clay Moltz, "The Russian Economic Crisis: Implications for Asian-Pacific Policy and Security," delivered at the conference "The Asia Pacific Security Region: Links Between Economic and Security Relations," La Jolla, Calif., 13-15 May 1993.

9.John Locke, "Essay Concerning Human Understanding."

10.Thomas Hobbes, Leviathan (London: Basic Blackwell Oxford, 1957), 112. 
11.John Herz explains, "Throughout history, that unit which afforded protection and security to human beings has tended to become the basic political unit; people, in the long run, will recognize that authority, any authority, which possesses the power of protection." John Herz, "Rise and Demise of the Territorial State" World Politics 9, no. 4 (July 1957), 474.

12. Weber attributes a state's legitimacy to tradition (as in the divine right of kings); law; or charismatic leadership. Russia's current problem may be explained in part by the fact that none of these legitimacy-enhancing institutions is at work in the RF today.

13.Georg Simmel, "The Web of Group-Affiliations" in Conflict and the Web of GroupAffiliations translated by Reinhard Bendix (New York: Free Press, 1955), 98-107. See also Charles Tilly, Coercion. Capital and European States, AD 990-1990 (Cambridge: Basil Blackwell, 1990), 67-95; and Michael Howard, "War and the Nation-state" Daedalus 108, no. 4 (Fall 1978), 101-110.

14.For a fascinating discussion of two competing theories about the implication of the end of the Cold War for the persistence of the modern state, see Michael Desch, "War and State Formation; Peace and State Deformation: The End of the Cold War and the Deconstruction of the Modern State," unpublished manuscript, University of California at Riverside, 1993. Desch argues quite convincingly that theories that attribute state unity to threats are far more compelling than those that claim that states will continue in their present form. Peace, he argues, may be the "undoing" of the modern nation-state.

15.H.H. Gerth and C. Wright Mills, From Max Weber: Essays in Sociology (New York: Oxford University Press, 1946), 78.

16.Ernest Gellner, Nations and Nationalism (Ithaca: Cornell University Press, 1983), 4-5. 17.The tribe and the city-state earned the loyalty of their members, but neither was able to amass great power. Empires tend to accumulate power, but not the loyalty of their subjects. 
Robert Gilpin, "The Global Political System" in J. D. B. Miller and R. J. Vincent, Order and Violence (Oxford: Clarendon Press, 1990), 116.

18. Coercion induces loyal behavior but not feelings of loyalty. Chafetz argues that a coercive regime is not legitimate because compliance will deteriorate when coercion is relaxed. See Glenn Chafetz, Gorbachey, Reform, and the Brezhney Doctrine (Westport, Connecticut: Praeger, 1993), 50.

19. Robert Gilpin, "The Global Political System," 118.

20.For a fascinating discussion of the emerging concept of nation as distinct from state in Russia, see Leokadia Drobizheva, "Perestroika and the Ethnic Consciousness of Russians" in Gail Lapidus and Victor Zaslavsky, eds., Erom Union to Commonwealth: Nationalism. and Separatism in the Soviet Renublics (New York: Cambridge University Press, 1992), 9899.

21."A state is a legal organization, based on a hierarchy of officials. A nation is a community of people who believe themselves to share a cultural heritage." Hugh Seton Watson, "Russian Nationalism in Historical Perspective" in Robert Conquest, ed., The Last Empire: Nationality and the Soviet Future (Stanford: Hoover Institution Press, 1986), 14. See also Gellner, 7; and Anthony D. Smith, "Ethnic Making and Territorial Nationalism" in Alexander Motyl. Thinking Theoretically About Soviet Nationalities (New York: Columbia University Press, 1992), 50.

22. The definition of nation is of course deeply political. Quebecois define nation in terms of language: Canadians in terms of geography and economic efficiency; Pakistanis in terms of religion; and Indians in terms of history and geography.

23.Joseph Stalin. "Marxism and the National Question" (New York: International, 1942), 12.

24.Nikita Moiseyev, an advisor to Yeltsin claims, "The most awful thing is that few are 
aware that we do not have a state yet. There is not even consensus on whether Russia will be a state based on territory, like the United States, or a nation of ethnic "nations," like the former Yugoslavia."

25.Ernst Haas, "What is Nationalism and Why Should We Study It?" International

Qreanization 40, no. 3 (Summer 1986), 710.

26.Pierre Hassner, "Beyond Nationalism and Internationalism" Survival 35, no. 2 (Summer 1993), 50.

27.The preceding paragraph is based on: John Plamenatz, "Two Types of Nationalism" in E. K.emenka, ed., Nationalism. The Nature of an Idea (Canberra: The Australian National University Press, 1973), 22-37; Jack Snyder, "Nationalism and the Crisis of the Post-Soviet State" Survival 35, no. 1 (Spring 1993): 5-26; Pierre Hassner. "Beyond Nationalism and Internationalism" Survival 35, no. 2 (Summer 1993); Anthony D. Smith, "Ethnic Making and Territorial Nationalism" in Alexander Motyl. Thinkino. Theoretically About Soviat Nationalities (New York: Columbia University Press, 1992), 61.

28.David Welsh. "Domestic Politics and Ethnic Conflict" Survival 35, no. I (Spring 1993). 66.

29. Exceptions include Chuvash, who are Christian, and Tuvans, who are predominantly Buddhist.

30.Ann Sheehy, "Russia's Republics: A Threat to Its Territorial Integrity?" REL-RL Research Report 10 May 1993.

31.Pierre Hassner, "Beyond Nationalism and Internationalism" Survival 25, no. 2 (Summer 1993), 51.

32.Jack Snyder, "Nationalism and the Crisis of the Post-Soviet State" Survival 35, no. 1, 12. Snyder, curiously, considers only Russian ethnic nationalism, and entirely ignores the nonRussian nationalities of the RF. 
33.Jack Snyder, "Nationalism and the Crisis of the Post-Soviet State," 12.

34.The nationalist themes emerging in the former Soviet Union are "familiar to specialists in ethnic relations," one such specialist explains. In ethnically mixed areas one expects to see a desire to control ones own territory. In developed regions, one anticipates aspirations to readjust revenue sharing. Although this specialist was referring to the former Soviet Union, the same themes have emerged in Russia. Donald D. Horowitz, "Soviet Ethnic Problems" in Alexander Motyl. Thinking Theoretically Aboul Sovies Nationalities (New York: Columbia University Press. 1992), 14.

35. See Jack Snyder, "Nationalism and the Crisis of the Post-Soviet State," 5-26.

36.N.G. Volkova and L.I. Lavrov. "Sovremennye etnicheskie protsessy." 330. Cited in Jane Ormrod. "The North Caucasus: Fragmentation or Federation'?" in lan Bremmer and Ray Taras, eds., Nations and Politics in the Sovies Successor States (New York: Cambridge University Press. 1993), 451. Paul Goble explains that In 1921.1922, when Stalin forced ethnic groups to identify themselves, they answered "human being" in their native language. Approximately 70 percent of the names of the 400 ethnic groups listed in the 1989 Soviet census mean "human being" in the relevant language. Paul Goble, "CIS, Boom, Bah: The Commonwealth of Independent States and the Post-Soviet Successor States," Speech at the Miller Center. 4 November 1992.

37.1 refer in this paragraph to the type of ethnic nationalism that has recently emerged in Russia. Ciail Fondahl. "Siberia: Native Peoples and Newcomers in Collision" in lan Bremmer and Ray Taras. eds. Nations and Politics in the Soviet Successor States (New York: Cambridge University Press. 1993).

For a discussion of 19th century Russian policies that strengthened ethnic identity among other groups, see Anthony D. Smith. "Ethnic Identity and Territorial Nationalism" in 
Alexander Motyl, Thinking Theoretically About Soviet Nationalities (New York: Columbia University Press, 1992), 56.

38. See for example, Paul Brass, "Language and National Identity in the Soviet Union and India" in Alexander Motyl, Thinkins Theoretically About Soviet Nationalities (New York: Columbia University Press, 1992); and Dru Gladney, Muslim Chinese:Ethnic Nationalism in the People's Republic of China (Harvard University Press, 1991).

39.See Richard Pipes, The Formation of the Soviet Union (Cambridge: Harvard University Press, 1954); and Victor Zaslavsky, "Success and Collapse: Traditional Soviet Nationality Policy" in lan Bremmer and Ray Taras, eds., Nations and Politics in the Soviet Successor States (New York: Cambridge University Press, 1993).

40.Lenin engaged in long arguments (in print) with his contemporaries about how to interpret the vague expression "right of self-determination," especially with Rosa Luxembourg. See V. I. Lenin. Questions of National Policy and Proletarian Internationalism (Moscow: Progress Publisher [no year]). 41.On the language question, see Lenin. 20. "If, in our political agitation, we fail to advance and advocate the slogan of the right to secession, we shall play into the hands, not only of the bourgeoisie, but also of the feudal landlords and the absolutism of the oppressor nation (i.e., the "Great Russians.") l.enin, p.69. Lenin did promote bilingualism. however. On the right of secession: "However meager the Russian Social-Democratic literature on the "right of nations to self-determination" may be, it nevertheless shows clearly that this right has always been understood to mean the right to secession." Lenin. 104. For a description of the development of Stalin's position (in opposition to Bukharin's) see Isaac Deutscher. Stalin: A Political Biography (New York: Oxford University Press, 1967). For discussion of post-Lenin Russification, see John Dunlop, "Language, Culture and Religion" in Robert 
Conquest, ed., The Last Empire: Nationality and the Soviet Euture (Stanford: Hoover

Institution Press, 1986), 266-272.

42.Joseph Stalin, Sochinenive vol. IV, 31-32. Cited in Isaac Deutscher, Stalini_A Political Biography 185.

Finland, Latvia, Lithuania. and White Russiu (Belarus) declared independence from the Soviet Union in 1917. Estonia, the Ukraine, Poland, and the Transcuucasian Federation (later dissolved into Azerbaijan, Georgia, and Armenia) followed in 1918. Of these, only Finland, and to a lesser extent Poland and the Baltic states were successful--the Baltics only until 1940.

Nicholas V. Riasanovsky, A History of Russia Sth ed. (New York: Oxford University Press. 1993), 484, 516.

43.See especially Walter A. Kolarz, "'Bussin and Her Coloniess (New York: Frederick A. Praeger, 1952); Samad Shaheen. The Communist Theory of National Self-Determination. (The Hague: W. Van Hoeve, 1956); Gail Lapidus, ed., The "Nationality" Question in the Soviat Union (New York: Garland Publishing Company, 1992): and lan Bremmer and Ray Taras, eds., Nations and Politics in the Soviel Successor States (New York: Cambridge University Press, 1993).

44.Lenin initially opposed organizing the Soviet state on the federalist principle. MarxistLeninist doctrine holds that not only national differences, but the state itself will eventually wither away.

45.Lenin, 193.

46.See for example Victor Zaslavsky, "Success and Collapse: Traditional Soviet Nationality Policy" in Ian Bremmer and Ray Taras, Nations and Polities in the Soviet Successor States (New York: Cambridge University Press, 1993), 29-42.

47.Ronald Suny, "Roots of the National Question" in Gail Lapidus and Victor Zaslavsky, 
eds., Erom Union Te Commonwealth (New York: Cambridge University Press, 1992), 29. Paul R. Brass, "Language and National Identity: Soviet Union and India" in Alexander Motyl. Thinkine Theoretically About Soviet Nationalities (New York: Columbia University Press, 1992), 113.

48. Richard Pipes, The Formation of the Soviet Union (Cambridge: Harvard University Press, 1954), 247.

49. Victor Zaslavsky, "Success and Collapse: Traditional Soviet Nationality Policy" in Ian Bremmer and Ray Taras, Nations and Politics in the Soviet Successor States (New York: Cambridge University Press, 1993), 39.

50.Rolf J. Lanhammer, Matthew J. Sagers and Matthias Lucke, "Regional Distribution of the Russian Federation's Export Earnings Outside the Former Soviet Union and its Implications for Regional Economic Autonomy" Pest-Soviet Geography 33, no. 10 (1992): 617.634 .

51.For more on this point, see Paul Goble, "Russian Break-Up" NEFTE Compass 2, no. 2 (15 January 1993): 10-12.

52.Two predominantly ethnic- Russian, relatively wealthy regions--Sverdlovsk oblast and Primorski krai--proclaimed themselves republics during the Constitutional Assembly in summer 1993. This is particularly surprising in the case of Sverdlovsk because of that oblast's consistent support for Yeltsin--who is from Sverdlovsk. James P. Gallagher, "Regional Discord Rips Russian Unity" Chicago Tribune, 27 June 1993. Ann Sheehy, "Rights of Subjects of Federation Recognized?" RFE-RL Daily Report. 17 June 1993; and Ann Sheehy, "Sverdlovsk Oblast Declares Itself Ural Republic" RFE-RL Daily Report, 2 July 1993.

53.For a more detailed discussion, see Richard Conquest, Soviet Deportation of Nationalities, 24. 
54.A Congress of Balkar People held in January 1992 adopted a resolution proclaiming a separate Balkar Republic; ninety-five percent of Balkars polled supported a separate Balkar Republic within the RF. V. Borisov, "The Number of Legal Entities Has Increased" Sovetskaya Rossiva 21 January 1992, p. 2; cited in FBIS-USR-92-009, 30 January 1992, 111. The Kabardino-Balkar parliament approved the restoration of a Kabardin Republic on its historical territory in February 1992. Dispute about how to divide the territory is delaying implementation of the plan. Igor Terekhov, "The Supreme Soviet Approved the 'Divorce' of Two Peoples," Nezavisimaya Gazeta 15 February 1992, p. 3. Printed in FBISUSR-92-030, 18 March 1992, 70; Alexander Aleshkin, "Is 'Divorce' Inevitable in Kabardino-Balkaria?" Rossiskaya Gazeta 23 May 1992, p. 2. Printed in FBIS-USR-92-073, 53.

55. Goble points out that this policy was necessary because of the location of the Far East Militaiy District in Chita oblast.

56.Ann Sheehy, "Buryat Parliament Declares Splitting Up of Republic in 1937 Unconstitutional" RFE-RL Daily Report 4 June 1993.

57. Conquest, 54.

58.See Ann Sheehy, "Russian Troops Placed on Alert in North Ossetia and Ingushetia" RFE-RL Daily Report, 21 June 1993.

$59.2 .3 \%$ of Ingush voters supported Yeltsin. For Galina Starovoitova's claim that Russia had sided with Ingushetia, see RFE-RL Weekly Review, 11-17 November, 1992. For referendum results, see Philip Smucker, "Russia; Regions Voted for More Autonomy From Moscow" Financial Times, 27 April 1993, 27. Ingushetia also threatened not to attend the Constitutional Assembly unless Yeltsin guaranteed that Ingush refugees could return to their homes in N. Ossetia. Ann Sheehy, "Ingush President May Not Attend Constitutional Assembly" RFE-RL News Briefs 3 June 1993. 
60.See Vera Tolz, "Russia's Kalmyk Republic Follows Its Own Course" $\underline{\text { REE-RL Research }}$ Report, 21 May 1993.

61.For a discussion of Soviet colonization of the Far East, see Walter Kolarz, The Peoples of the Soviet Far East (New York: Frederick A. Praeger), 1954.

62.Paul Goble, "Russian Break-Up" NEFTE Compass 2, no. 2 (15 January 1993), 11.

63.Nicholas V. Riasanovsky, A History of Russia 5th ed. (New York: Oxford University Press, 1993), 23-60; 67-87. Riasanovsky dates Kievan Rus from 882 to 1240.

64.For a fascinating discussion of the birth of the Ukrainian state (as distinct from Russia), see Anthony D. Smith, "Ethnic Identity and Territorial Nationalism" in Alexander Motyl, Thinking Theoretically About Soviet Nationalities (New York: Columbia University Press, 1992), 48.

65.The Muscovite state displayed a marked proclivity for expansion. The Muscovite kingdom began with 430,000 square kilometers in 1480 , and acquired an average of 35,000 square kilometers per year in the succeeding 150 years. Richard Pipes, Russia Under the Old Regime (New York: Scribners, 1974), 83.

66.Nicholas V. Riasanovsky, A History of Russia 5th ed. (New York: Oxford University Press, 1993); Robert Conquest, The Soviet Deportation of Nationalities (New York: St. Martin's Press, 1960); Walter Kolarz, The Peoples of the Soviet Far East (New York: Frederick A. Praeger, 1954).

67.Aleksandr Solzhenitsyn, "How Shall We Reconstitute Russia?" Literaturnaya Gazeta, 18 September 1990. Cited and analyzed in John Dunlop "Russia: Confronting a Loss of Empire" in Ian Bremmer and Ray Taras, eds., Nations and Politics of the Soviet Successor $\underline{\text { States }}$ (New York: Cambridge University Press, 1993) and John Dunlop, "Solzhenitsyn Calls for the Dismemberment of the Soviet Union," Report on the USSR 14 December 1990, 3-4. 
68.See for example, V. Lvova, "Who Will Protect the Russians?" Express Chronicle 307, no. 25, 25 June 1993.

69.Rowland Evans and Robert Novak, "Yeltsin's Challenge" Washington Post 26 April 1993.

70.N. V. Petrov, S. S. Mixeev, and L. V. Smirnyagin, "Situatsia v Regionax na 12/1/92," (unpublished manuscript) Moscow: Center for Political-Geographical Research, 1992. 71.See Clay Moltz, "Panel on Patterns of Disintegration in the Former USSR" Post-Soviet Geography XXXIII, no. 6, p. 370. Citing Far Eastern Economic Review January 16, 1992. 72.Georgi Vachnadze, Goryachiye Tochki Rossii (Marburg, Germany: Blaue Horner Verlag, 1993), 78.

73.Clay Moltz, in "Panel on Patterns of Disintegration in the Former USSR" Post-Soviet Geography XXXIII, no. 6, p. 369.

74.Clay Moltz, in "Panel on Patterns of Disintegration in the Former USSR" Post-Soviet Geography XXXIII, no. 6, p. 370.

75.See generally Eye on Supply, Emerging Nuclear Suppliers Project, Monterey Institute of International Studies.

76. William C. Potter, "Nuclear Exports From the Former Soviet Union: What's New, What's True," Arms Control Today 23, no. 1 (January/February 1993), 8.

77.Celestine Bohlen, "Amid Nuclear Transition, Russia's Scientific Elite Loses Its Security" New York Times 11 July 1993; Nuclear Weapons Workers Issue Strike Warning" $\underline{\text { RFE/RL }}$ Daily Report, 7 July 1993.

78.Galina Starovoiteva, "Nationality Policies in the Period of Perestroika: Some Comments From a Political Actor" in Gail Lapidus and Victor Zaslavsky, eds., From Union to Commonwealth: Nationalism and Separatism in the Soviet Republics (New York: Cambridge University Press, 1992), 116. 
79.Hedley Bull, The Anarchical Society (New York: Columbia University Press, 1977), 4-5. 80.Sheila Marnie and Albert Motivans, "Rising Crime Rates: Perceptions and Reality" RFERL Research Report no. 16, 16 April 1993.

81."The Rouble Used as a Bomb" Economist 31 July 1993, 41.

82.Peter J. Stavrakis, "The Russian Government's Bureaucracies: Transition or Disintegration?" RFE-RL Research Report, 29 April 1993.

83.Peter J. Stavrakis, "The Russian Government's Bureaucracies: Transition or Disintegration?" RFE-RL Research Report, 29 April 1993.

84."The Rouble Used as a Bomb" Economist 31 July 1993, 41.

85. Charles H. Fairbanks, "After the Moscow Coup" Journal of Democracy 2, no. 4 (Fall 1991), 4.

86.See for example, Timur Muzaev, "Opposition Hides From Dudaev" Express Chronicle 306, no. 24, 18 June 1993.

87.The president bribed the parliament (by offering them interest free loans) to approve bills abolishing all local councils and reducing the parliament's number from 130 to 25 . In order to receive the loans, the parliamentarians had to agree to renounce politics and go into business. RF parliamentarians have hinted that they too might be susceptible to similar bribes, such as Moscow apartments, life-long salaries, and priority booking on trains and planes. "A Foreign Aid Opportunity" Economist 29 May 1993.

88.Vera Tolz, "Russia's Kalmyk Republic Follows Its Own Course" RFE-RL Research Report 21 May 1993.

89.See for example, Ann Sheehy, "Constitutional Court Ruling on Moldova" RFE-RL News Briefs 4 June 1993.

90.Vladimir Yemelyanenko, "The Country Will Collapse" Moscow News 7 February 1993; 
John Lloyd and Dmitri Volkov, "Constitutional Reform a Step Closer in Russia" Financial Times 12 July 1993, 2.

91.Yelena Pestrukhina, "Shakhrai Puts Forth 11 Principles" Megapolis-Express, 3 March 1993, p. 13. Reported in The Current Digest of the Post-Soviet Press XLV, no. 9 (31 March 1993), 11.

92.Paul Goble, "Russia Break-Up" NEFTE Compass 2, no. 2 (15 January 1993), 11. 93.One example is the Tatar Milli Mejlis. Radicals in Tatarstan hope that the parallel parliament will eventually supersede the existing one. Artyom Karapetyan, "Nationalist Passions in Tatarstan" Moscow News 22 January 1992.

94.Vladimir Yemelyanenko, "The Country Will Collapse" Moscow News 7 February 1993. 95.Ann Sheehy, "Deputy Premier Fedorov on Demands of Republics" RFE/RL Daily Report, 4 June 1993.

96. RA Report 14, January 1993, 70.

97."Tatarstan Wins More Independence" Commersant 30 June 1993, 5.

98. Yelena Pestrukhina, "Shakhrai Puts Forth 11 Principles" Megapolis-Express, 3 March 1993, p. 13. Reported in The Current Digest of the Post-Soviet Press XLV, no. 9 (31 March 1993), 11.

99.Lidia Malash, Interview with Anatoly Antonov, Director of the Center for SocioStrategic Research, Magapolis-Express, in Current Digest of the Post-Soviet Press, 17 March 1993.

100.Stephen Foye, "Rutskoi Hits Yeltsin on State of the Army" RFE-RL Daily Report 18 June 1993.

101.Flora Zainullina, second in command of Ittifak. Quoted in Georgi Vachnadze, "Goryachiye Tochkii Rossii," 128.

102.A. Putko, "How It is Being Proposed that the Tatars Free Themselves from the 
'Russian Yoke'" Izvestia 25 November 1991, p.4. Reported in Current Digest of the Soviet Press 25 December 1991.

103.Ron Wixman, "The Middle Volga: Ethnic Archipelago" in lan Bremmer and Ray Taras, Nations and Politics in the Soviet Successor States (New York: Cambridge University Press, 1993), 429.

104.Ron Wixman, "The Middle Volga: Ethnic Archipelago" in lan Bremmer and Ray Taras, Nations and Politics in the Soviet Successor States (New York: Cambridge University Press, 1993), 430.

105.Justin Burke, "Yeltsin Faces Nationalist Protest" Christian Science Monitor 23 April $1991,6$.

106.Carroll Bogert, "Wanting Out of Russia" Newsweek 12 November 1990, 40.

107."Shaymiyev Reiterates Dedication to Union with Russia," Postfactum, 26 January 1992. Reported by British Broadcasting Corporation" 28 January 1992, p. SU/1289/B/1. 108.Viktor Radziyevsky, "Tatarstan, Bashkortostan and the Federation Treaty" Moscow News 6 May 1992.

109.Radik Batyrshin, "Tatars Dissatisfied with Conference" FBIS-SOV-93-121, 25 June $1993,20$.

110.Paul Goble, "Constitutional Splits" NEFTE Compass. v, no. 24 (17 June 1993), 10.

111."Shaymiyev Reiterates Dedication to Union with Russia," Postfactum, 26 January 1992. Reported by British Broadcasting Corporation" 28 January 1992, p. SU/1289/B/1.

112."Tatar Parties Protest at Leadership's Inactivity" Interfax News Agency, Moscow, 18 July 1992. Reported in BBC Summary of World Broadcasts, 20 July 1992, p. SU/1437/B/1. 113.Dmitri Mikhaylin, "Report on Tatarstan Parliament Session Activity" FBIS-USR-92070, 10 June 1992, 51. Originally published in Rossiskaya Gazeta 26 May 1992, 1. 114.N. Morozov, "View From a Region: Tatarstan-- A People's Militia is Being Created" 
Pravda 16 October 1991, pp. 1, 3. Reported in Current Digest of the Soviet Press XLIII, no. 42, p. 28. See also "Tatar Young Men Evade Conscription" BBC Summary of World Broadcasts, 19 August 1992. p. SU/1463/C4/1.

115.Statement by Vyacheslav Ogorodnikov, director of "an administration" of the Ministry of Internal Affairs. Yelena Pestrukhina, "Shakhrai Puts Forth 11 Principles" MegapolisExpress, 3 March 1993, p. 13. Transcribed in The Current Digest of the Post-Soviet Press XLV, no. 9 (31 March 1993), 11.

116."Tatar Calls for Volga-Ural Confederation" RFE-RL Weekly Report, 2 December 1992. 117. Vachnadze, 121 .

118. Bashkirs comprise $22 \%$ of the population of Bashkortostan; Russians $39 \%$; and Tatars 28.4\%. All statistics from Ron Wixman, "The Middle Volga: Ethnic Archipelago" in lan Bremmer and Ray Taras, Nations and Politics in the Soviet Successor States (New York: Cambridge University Press, 1993).

119.Chuvash are predominantly Christian. Bashkirs, like Tatars, are predominantly Muslim. but Wixman notes that shamanism/animism still thrives in Bashkortostan. For a fascinating discussion of the cultures and religions of this region, see Ron Wixman, "The Middle Volga: Ethnic Archipelago" in lan Bremmer and Ray Taras, Nations and Politics in the Soviet Successor States (New York: Cambridge University Press, 1993). 120.Vitaly Portnikov, "Tataria: The Kremlin Under the Crescent" Nezavisimaya Gazeta 26 November 1991. [Reported] in Current Digest of the Soviet Press XLIII, no. 47, 25 December 1991, p. 1 .

121. Vachnadze explains, "Arzamas 16 is still governed by three masters - the land belongs to Mordova, the city council operates under Gorki regional administration, and all industrial sectors depend on the military-industrial complex." Georgi Vachnadze, 110. 122.Robert Norris, "The Nuclear Archipelago" Arms Control Today 22, no. 1 
(January/February 1992), 28-29. Norris lists sites by the names of the towns in which they are located, without naming the republic or oblast.

123. William C. Potter, "Nuclear Profiles of the Soviet Successor States" Monterey Institute of International Studies, April 1993.

124.Robert Norris, "The Nuclear Archipelago" Arms Control Today 22, no. 1

(January/February 1992), 28-29. Norris lists sites by the names of the towns in which they are located, without naming the republic or oblast.

125.Vachnadze, 107.

126. Vachnadze, 111 .

127. Vachnadze, 126.

128.Oil refining takes place at Ryazan and Nizhny Novgorod.

129.Carroll Bogert, "Wanting Out of Russia" Newsweek 12 November 1990, 40.

130. Note that the next biggest exporter of machinery and equipment is the Moscow oblast, which accounts for $12.7 \%$ of Russia's total exports in this sector. Rolf J. Langhammer, Matthew J. Sagers and Matthias Lucke, "Regional Distribution of the Russian Federation's Export Earnings Outside the Former Soviet Union and Its implications for Regional Economic Autonomy" Post-Soviet Geography 33, no. 10 (1992): 617-634.

131. Russia's export earnings are highly concentrated. Most of Russia's wealth is not in the republics, but three out of five republics that contributed from $1 \%$ to $5 \%$ are in the VolgaUrals region. The five are Karelia, Sakha, Bashkortostan, Tatarstan, and Komi. Rolf J. Langhammer, Matthew J. Sagers and Matthias Lucke, "Regional Distribution of the Russian Federation's Export Earnings Outside the Former Soviet Union and Its Implications for Regional Economic Autonomy" Post-Soviet Geography 33, no. 10 (1992), 627.

132. The five neighboring republics include the Turkic republics of Bashkortostan and Chuvash, and the Finnic republics of Udmurtia, Mari El, and Mordova. 
133.Vitaly Portnikov, "Tataria: The Kremlin Under the Crescent" Nezavisimaya Gazeta 26

November 1991. [Reported] in Current Dipest of the Soviet Press XLIII, no. 47, 25

December 1991, p. 1.

134. Tatarstan and Bashkortostan, in contrast, are considered to be "extremely unstable areas." "Russian Investment Risks Mapped" Commersant 28 April, 1993.

135.By support, I mean over $50 \%$ of the voters expressed trust in the president. See "Russian Referendum" Einancial Times 28 April 1993, 2.

136. Ralph Boulton, "Proclamation of Urals Republic Sends Warning to Yeltsin" Reuter Library Report 2 July 1993.

137."The nationalists assign paramount importance not to the rights of the individual but to the rights of the nation, and the migration of Russians out of Tatarstan may begin soon." an ethnic-Russian citizen of Tatarstan complained. Yevgeny Shukin, "Ordinary Ittifak Fascism?" Bessiskaya Gazeta, 28 November 1993, p. 3. Reported in Current Divest of the Soviet Press XLVII, no. 47, (December 25, 1991), p. 5.

138. Members of the Greater Volga (Bolshaya Volga) Economic Association include Astrakhan', Volgograd, Samara (Kubyshev), Saratov, Penza, Simbirsk (Ul'yanovsk) and Nizhniy Novgorod (Gor'kiy) oblasts; and Kalmykia, Tatarstan, Chuvash, and Mordova republics. Members of the Greater Urals (Bolshoi Ural) Economic Association include Kurgan, Orenburg, Perm', Yekaterinburg (Sverdlovsk), Cheyabinsk, and Tyumen oblasts: and Bashkortostan and Udmurtia republics. Source: Jean Radvanyi. "And What if Russia Breaks UP: Toward New Regions Divisions" Post Soviel Geography 33, no. 2 (Feb 1992), 73.

139. Vachnadze, 15.

140.John Lloyd, Russia Begins to Fray At the Edges" Financial Times 9 July 1993, 2. 



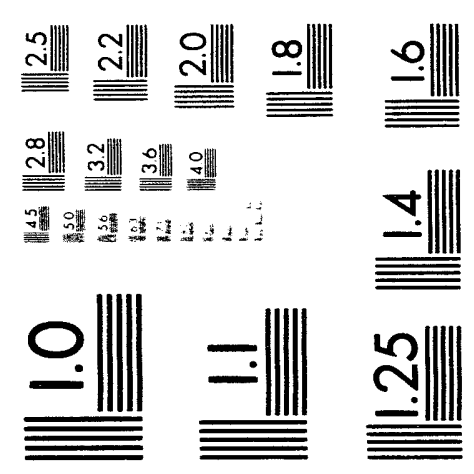



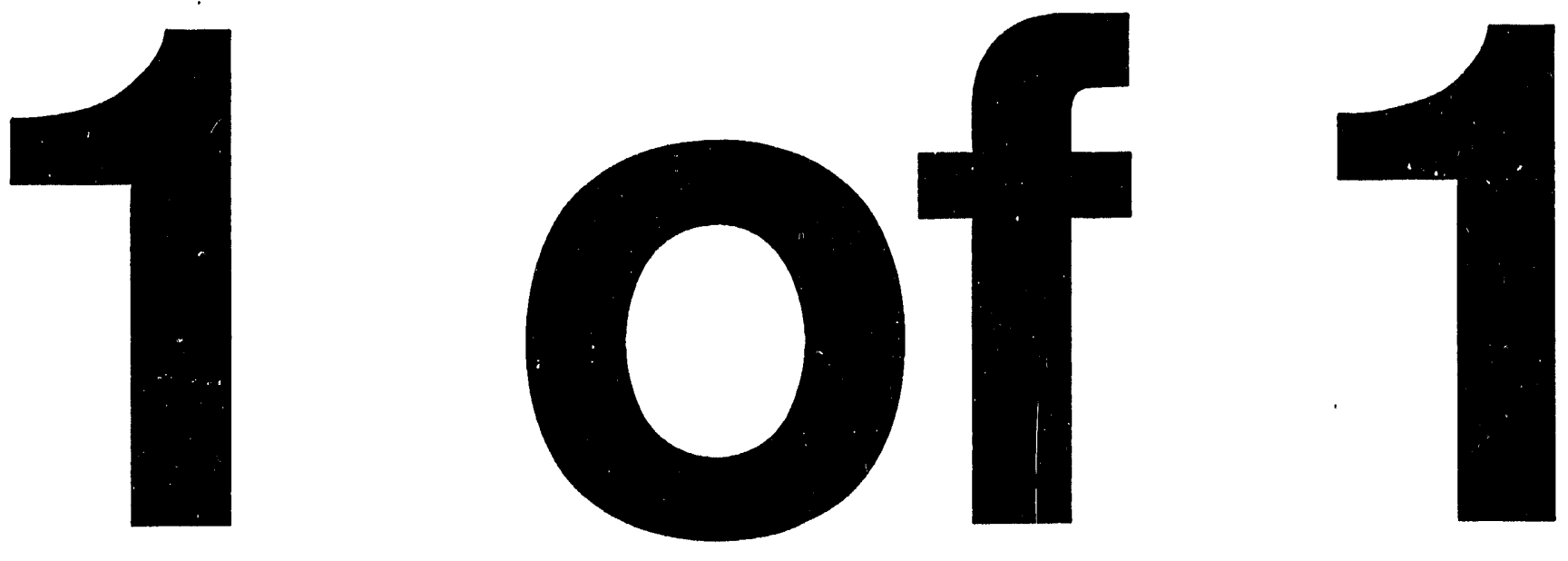


\title{
Why Russia is Not a State
}

\author{
Jessica E. Stern
}

August 16, 1993

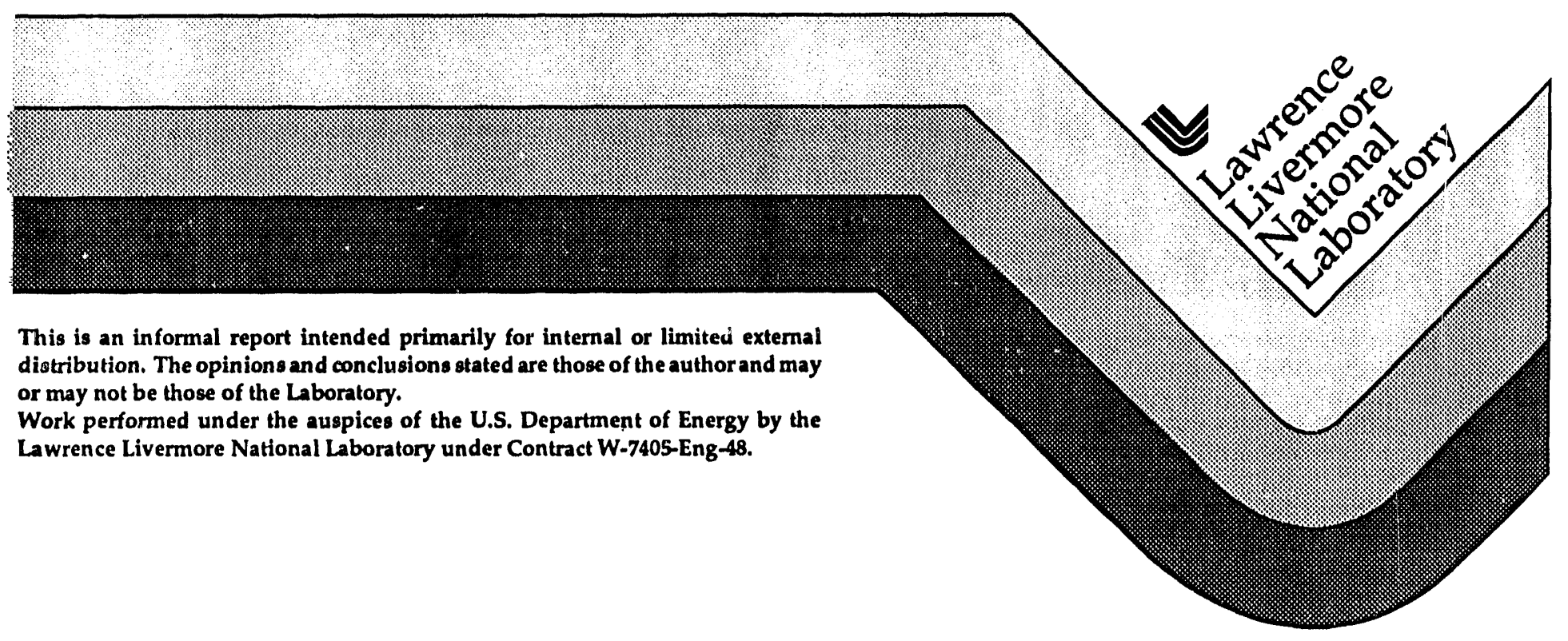

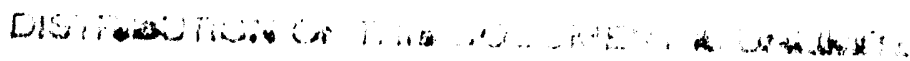




\section{DISCLAIMER}

This document was prepared as an account of work sponsored by an agency of the United States Government. Neither the United States Government nor the University of California nor any of their employees, makes any warranty, express or implied, or assumes any legal liability or responsibility for the accuracy, completeness, or usefulness of any information, apparatus, product, or process disclosed, or represents that its use would not infringe privately owned rights. Reference herein to an y specific commercial products, process, or service by trade name, trademark, manufacturer, or otherwise, does not necessarily constitute or imply its endorsement, recommendation, or fa voring by the United States Government or the University of California. The views and opinions of authors expressed herein do not necessarily state or reflect those of the United States Government or the University of California, and shall not be used for advertising or product endorsement purposes.

This report has been reproduced directly from the best available copy.

A vailable to DOE and DOE contractors from the Office of Scientific and Technical Information P.O. Box 62, Oak Ridge, TN 37831

Prices available from (615) 576-8401, FTS 626.8401

A vailable to the public from the

National Technical Information Service

U.S. Department of Commerce

5285 Port Royal Rd.

Springfield, VA 22161 


\title{
Why Russia is Not a State
}

\author{
Jessica Eve Stern \\ Lawrence Livermore National Laboratory \\ PO Box 808 L205 \\ Livermore, CA 94551 \\ Phone: 5104227071 \\ Fax: 5104234077 \\ internet: jstern@llnl.gov \\ 9/10/93
}

This research was supported by Lawrence Livermore National Laboratory. The views expressed herein are those of the author and not necessarily those of the U.S. government.

I would like to thank Glenn Chafetz, Paul Chrzanowski, Jerry Dzakowic, Paul Goble, Peter Lavoy, Amy Sands, and David Wolff for helpful comments. 


\section{Why Russia Is Not A State}

Moscow's deteriorating relationship with former Soviet republics has been widely noted in the press. Less well known is that the process that led to the break-up of the Soviet Union is continuing within the Russian Federation itself. The most significant threats to the security of the Russian state stem from within the Russian Federation. Deputy Prime Minister Boris Fedorov recently conceded that he is more worried about separatist Tatarstan than he is about Ukraine, despite Ukraine's reluctance to relinquish the former Soviet nuclear weapons on its soil.'

This article makes two principal points. First, I argue that the Russian federation has never been a state and is not sustainable as a state. Four centrifugal indicators are presented to support this claim: ethnic divisiveness; uncertainty about the legitimacy of Russia's current borders; competing claims for legitimacy on the part of federal and regional leaders; and army units' unpredictable allegiances.

Second, I argue that Soviet policies intended to facilitate central control of the periphery had the perverse effect of creating ethnic identity and demands for national autonomy where, in many cases, they did not exist prior to the Communist regime. The establishment of a federal state based on ethnic divisions gave ethnic groups the expectation and, in some cases the administrative infrastructure, of national statehood. Marxist-Leninist theory holds that ethnic distinctions will eventually lose their political significance and that nationalist sentiments will fade away. Instead, the late 20th century has witnessed the fragmentation of the Soviet empire into its constituent, ethnically-defined parts. Unless Yeltsin and his successors find the precise balance between indulging and disciplining 
separatist regions, this fragmentation process will continue within the Russian Federation itself.

The Russian government is increasingly unable to meet its obligations as a sovereign power. Deputy Prime Minister Fedorov recently admitted that the government is failing in its public duty to protect citizens and their currency, ${ }^{2}$ and that he worries about Moscow's ability to maintain macroeconomic control of Russia. ${ }^{3}$ Russians are increasingly conducting business in dollars and in the Far East, in Chinese yuan. ${ }^{4}$ Russian statistics report that the crime rate has nearly doubled since 1985 . $^{5}$ The armed forces are beset by conscription problems and lack of funds. ${ }^{6}$ There is no longer a clear outside threat against which Russia must defend its citizens; and the internal threats to Russia's integrity are proving increasingly difficult to overcome. Russia's new military doctrine reflects concerns about both external and internal threats to Russian Federation (RF) security. ${ }^{7}$

Changing political and economic circumstances have made nationalism a useful political tool in Russia just as it was at the time of the Revolution. Ethnic strife is rippling below the surface in some areas, such as in Buryatia. Other republics are engaged in open internecine conflict. Ingush are demanding to reclaim territory Stalin took from them in North Ossetia. North and South Ossetians are agitating for an "Ossetian Republic" that would encompass the South Ossetian autonomous republic, now part of Georgia. Kabardins and Balkars are trying to split into two autonomous republics.

Intelligence analysts and policy makers should pay closer attention to Russia's potential fragmentation for three reasons: nuclear facilities are located in some of the most volatile regions; army units show greater allegiance to the regions than to the center in some areas; and the possibility of accidents at nuclear facilities is increasing. If former governor of Sakhalin Valentin Fedorov's threat to revive the 1920s Far Eastern Republic were carried out, for example, that republic could be the third largest nuclear power in the 
world. ${ }^{8}$ Political fragmentation of the RF could also loosen control over sensitive exports and increase the risk of terrorist acquisition of fissile materials.

Following the introduction, part one briefly reviews the concepts of state, nation, and nationalism and the roles they play in Russia. Criteria for state-hood are discussed. Part two lists the main ethnic groups in Russia and considers the roots of ethnic nationalism in the Russian Federation. Part three discusses confusion over the legitimacy of the physical, economic, and political boundaries of the Russian Federation. Part four discusses political disarray in the center and in the regions and the lack of unity among order-enforcing entities. The Volga-Ural region--where there is a large concentration of nuclear weapons and facilities, and which is especially volatile politically--is discussed in somewhat more detail. Part five argues that these factors taken together call into question Russia's identity as a state.

I conclude that Russia remains a multi-ethnic empire in which the rule of law is still not supreme. Under Communist rule, the KGB and the party were the order-enforcing entities that defined the state; the constitution and the law were niceties to which leaders paid heed only when it served their interests. Tyranny teaches disdain for law; but democracy cannot exist without respect for it. If there is one attribute of homo Sovieticus that appears truly to have taken root in Russia, it is scorn for the rule of law. Under postCommunist rule, the KGB and the party no longer serve their traditional order-enforcing functions, and disdain for the law has not been unlearned overnight. In post-communist Russia, chaos has replaced order; license has replaced terror. Order-enforcing entities are eviscerated or in conflict. Neither economic shock therapy nor G7 funds can help; Russia will not be a state until new unifying institutions are created--whether democratic or authoritarian.

\section{PART 1: CONCEPTS OF STATE, NATION, AND NATIONALISM}


Political philosophers have wrestled with the ideas of the state and political authority for centuries. The philosophy of the enlightenment held that the universe was governed by an unvarying law of Nature which is intelligible to every person of reason. Societies formed on the basis of natural law would flourish with little intervention. The sole function of the state was to preserve and guarantee the natural rights of persons and to settle disputes that might arise. ${ }^{9}$

Hobbes, in contrast, believed that people are by nature selfish and destructive; a state was necessary "to defend them [citizens] from the invasion of foreigners, and the injuries of one another, and thereby to secure them in such sort, as that by their own industry..they may nourish themselves and live contentedly..."10

Later attempts to define the state have built upon Hobbes' ideal type, focusing on three interrelated concepts: power--in the sense that the state can defend its interests abroad; ${ }^{\prime \prime}$ legitimacy--in the sense that the state commands the loyalty of its citizens; ${ }^{12}$ and order--in the sense that the state is able to protect citizens in their person and property.

A vast literature considers the relationship between power and the state. Georg Simmel, for example, concludes that war was crucial to the development of the modern state. ${ }^{13}$ When the threat of war recedes, states' internal cohesion deteriorates, according to this view. The implication of the theory is that the collapse of external threats coincident with the end of the Cold War may be hazardous to the continuing viability of states, particularly for the superpowers. ${ }^{14}$

Max Weber defines the state in terms of its ability to promote order: the state is that entity in society that claims a monopoly on the legitimate use of physical force. ${ }^{15}$ Ernest Gellner refines Max Weber's definition of the state as the institution or set of institutions "specifically concerned with the enforcement of order."16 
The distinguishing feature of the modern state is its success in resolving the trade-off between loyalty and power, in Robert Gilpin's view. ${ }^{17}$ States amass power and command citizens' loyalty--some by threatening violence or by building walls to keep citizens inside; others (more successfully) by creating what Macchiavelli called a "civic religion" or civic nationalism (discussed below). ${ }^{18}$ Most importantly, there is no authority superior to the state and no morality binding upon it; the state, at least in its ideal form, is the most powerful institution within its physical boundaries. ${ }^{19}$

The test of state-hood cannot be whether all citizens are loyal to the sovereign or feel safe from violence to their person and property. No modern state would meet this test; the question must be one of degree. Instead we will ask whether the Russian government is the most authoritative order-creating entity on the territory of the RF; whether citizens on average display more loyalty to Russia than to their oblast or republic or ethnic group; and whether the Russian government is the most powerful institution on the territory it controls. The remainder of this article considers these questions. It is necessary to define a few more terms, however, before turning to these questions.

A nation is not necessarily the same thing as a state. ${ }^{20}$ Two people are of the same nation if and only if they see themselves as such, whereas whether they are citizens of the same state can be empirically verified. ${ }^{21}$ Those who differentiate between nations and states tend to define nations in terms of culture and states in terms of government. ${ }^{22}$ Stalin, for example, who began his S defined a nation as an "historically constituted, stable community of people, formed on the basis of a common language, territory, economic life, and psychological make-up manifested in a common culture. ${ }^{.23}$

The distinction between nation and state is at the heart of the problem of nationalism and indeed, at the heart of Russia's problem today: ethnic nationalism often arises when 
members of a particular ethnic group believe themselves to be mistreated by the state. ${ }^{24}$ Such feelings may give rise to the desire for ethnic autonomy or national independence or, in the extreme case, competing claims for political legitimacy among federal and local ethnic leaders. Ernst Haas explains, "Nationalism can hold a society together while people are being buffeted by the strains of modernization... [but it] can take two forms: people under stress can seek to resolve it [the stress] by identifying with the existing state, but they can also look for help by seceding from it." 25

In the Soviet Union, ethnic consciousness was intensified by deliberate policies, including conflation of ethnic and political divisions in the federal structure of the state (both at the union and republic level); by intermittent promotion of national cultures and languages; by preferential treatment of ethnic minorities within their own republics-including ethnic quotas in regional administrations and in higher education; by deportation of entire ethnic groups; and by the practice of identifying citizens by ethnic group on internal passports. These policies are discussed in more detail in the next section. Heightened ethnic awareness, coupled with the wide-spread perception that Moscow took advantage of the non-Russian areas of the RF and gravely mistreated non-Russian nationalities, has created a situation ripe for ethnic conflict.

It is also useful to distinguish between ethnic nationalism and civic nationalism. Civic nationalism, which is based on law and the idea of equal rights for all citizens within a given territory, can exist only (but not necessarily) in well functioning democracies. ${ }^{26}$ Scholars describe this first type of nationalism as characteristic of Western democracies. Ethnic nationalism, characteristic of Eastern Europe, is based on common culture -- defined in terms of race, language, tradition or religion. Ethnic nationalism tends to flourish when state institutions fail, which some scholars claim explains the rise of ethnic nationalism in post-Soviet Russia and throughout the post-Communist world. ${ }^{27}$ 
Ethnic nationalism may also be kindled by democratic reforms, especially if those reforms do not include protection of equal rights for all ethnic groups. Ethnic nationalism and democracy are "intimately, if not symbiotically, linked," David Welsh claims. "If democracy means, "the people shall rule," then who are the people?... Thus is opened the way to invidious questions about the status and rights of particular categories of people."28

\section{PART 2: THE RISE OF ETHNIC NATIONALISM IN RUSSIA}

\section{Ethnic Groups}

Twenty-five million ethnic Russians live in former Soviet republics outside of the Russian Federation. Thirty million non-ethnic Russians (comprising over 100 ethnic groups) live within the Russian federation out of a total population of 150 million. Of these, Tatars are the most numerous, followed by Ukrainians, Chuvash, Bashkirs, Belarussians, Mordovans, and Chechens.

The Russian Federation is comprised of forty-nine administratively defined oblasts (provinces) and six similarly defined krais (territories), twenty-one ethnic republics, ten ethnic okrugs (areas), one ethno-religiously defined autonomous oblast, and two citysubjects. Of the 89 "subjects" of the RF, the twenty-one autonomous republics pose the gravest threat to the integrity of the RF by virtue of their escalating demands for economic and political autonomy. They are peopled by Finno-Ugric (Karelian, Komi, Udmurt, Mari, Mordvin); Caucasian (Adygey, Chechen, Cherkess, Dagestani, Ingush, Karbardin); Mongolian (Kalmuk, Buryat); Turkic (Altay, Bashkir, Balkar, Chuvash, Karachay, Khakass, Tatar, Tuvan, Yakut) and Iranian (Ossetian) peoples, Four religions are represented among them: the Finno-Ugric ethnic groups are a mix of Eastern Orthodox and Shamanist; the Caucasian and Turkic groups are predominantly Muslim; ${ }^{29}$ the N. Ossetians are Eastern 
Orthodox; and Tuvans and the Mongolian group are predominantly Buddhist. Those ethnic groups that profess Christianity tend to be the most assimilated in Russia. ${ }^{30}$

\section{The Causes of Ethnic Nationalism in Russia}

Recently there has been a great deal of debate about the rise of nationalism in Eastern Europe. Pierre Hassner argues that states are capable of tolerating ethnic diversity if they display one or more of the following characteristics: a strong central government, a common ideological bond, or a tradition of respect for individual rights. All tinree are lacking in post-communist Russia, however, paving the way for ethnic conflict. ${ }^{31}$

Jack Snyder argues that the prevailing view that ethnic nationalism will emerge in post-Soviet Russia is too pessimistic. ${ }^{32}$ He finds that civic nationalism suits Yeltsin's strategies for unifying a multiethnic society and for transition to a free market economy. ${ }^{33}$ But Snyder fails to note that ethnic nationalism suits the strategy of republican leaders (leaders of the autonomous republics of the Russian Federation), who are fanning the flames of ethnic nationalism with at least three objectives in mind: to solidify regional political support; to push for greater economic and political autonomy; and to deflect disappointment with the results of economic reform back to Moscow. ${ }^{34}$ Some republican leaders' true motivation for inciting ethnic unrest may have more to do with a desire to enhance their own personal power and the republics' share of resource revenues. But if republican leaders are using nationalist propaganda for their own objectives, they are only following a hallowed tradition of power-politics, and a common method of creating political legitimacy.

Contrary to popular conception, ancient, ingrained animosity is not the motivating force behind ethnic nationalism in Russia. ${ }^{35}$ Even in the Northern Caucasus, an area rife with ethnic tensions today, national consciousness is largely a 20 th century phenomenon. Prior to Communist rule, the ethnic groups of the Northern Caucasus saw themselves first 
as members of clans, and secondarily as members of a huge ethnic society of North Caucasian peoples. ${ }^{36}$ Two Soviet policies were critical to the development of national consciousness in the region: the 1921-22 creation of ethnically defined republics, and Stalin's 1944 deportation of the entire populations of the Karachay, Ingush, Balkar and Chechen national groups. Similarly, national consciousness among indigenous peoples of Siberia did not exist prior to the Soviet regime. ${ }^{37}$ The government's essential role in politicizing ethnic groups is not unique to Russia. Scholars note the decisive role of the state in politicizing ethnicity among Muslim Chinese and among many of the national groups in India. ${ }^{38}$

Ethnic tensions in Russia are largely attributable to Soviet nationalities policies implemented in the first three decades of Communist rule. Lenin astutely recognized the latent power of ethnic consciousness, and cynically used nationalist sentiment to attract the support of ethnic groups suppressed by Tsarist rule. ${ }^{39}$ The right of nations to selfdetermination was the cornerstone of the Bolshevik program between the end of the first World War and $1917 .^{40}$ Lenin not only opposed forcing non-ethnic Russians to adopt the Russian language but, in contrast to Bukharin, persistently defended nations' right to secede. $^{41}$ When Ukraine (in the spirit of self-determination) refused to allow Red Army troops on its soil in 1918, Lenin's Commissar of Nationalities, Joseph Stalin, advocated a reinterpretation of the right of national self-determination: "The principle of selfdetermination ought to be used as a means in the struggle for socialism and it ought to be subordinated to the principles of socialism." Moreover, the principle applied only to the "toilers" and not to the bourgeoisie. ${ }^{42}$

Lenin and Stalin implemented a number of policies to increase regions' dependence on the center, weaken ethnic power blocs, and crush secessionist aspirations. Five of these policies are highlighted here; others are considered elsewhere in the literature. ${ }^{43}$ All five 
strategies have had the unintended effect of further politicizing ethnic groups. The first strategy was to organize the Soviet Union as a confederation of fifteen union republics, most of which were dominated by a single ethnic group. ${ }^{44}$ (I will use the term "union republics" to refer to the fifteen former Soviet republics. The term "republics" will refer to autonomous republics within the Russian Federation.) The union republics were granted a semblance of autonomy including, as mentioned above, the right to secede--a right that was never expected to be taken seriously. All real power in this Soviet form of federalism was held by the center--by the Communist party, the KGB, and the planners of the command economy. When the party began to weaken in 1990 , the union republics used the paper autonomy Lenin gave them to demand more independence and, ultimately, to secede.

Lenin professed the desire that Communism correct and even make up for Tsarist policies of oppression of non-Russian nationalities. In 1922 Lenin claimed,

A distinction must necessarily be made between the nationalism of an oppressor nation and that of an oppressed nation, the nationalism of a big nation and a small nation...[W]e nationalists of a big nation, have nearly always been guilty, in historical practice, of an infinite number of causes of violence... That is why internationalism on the part of oppressors or 'great' nations...must consist not only in the observance of the formal equality of nations but even in an inequality of the oppressor nation. ${ }^{45}$

Critics argue that the Lenin's policies of granting the appearance of autonomy to national groups (including "nativization" policies, which granted special privileges to minorities and promoted regional cultures and languages) were devised to appease separatism, rather than to make up for the sins of the "oppressor nation." 46 Whatever Lenin's true motivations, however, Russian chauvinism was quickly revived under Stalin's rule in the 1930s. The federal state structure was preserved, but support for nationalities and regional autonomy were drastically reduced. ${ }^{47}$

Ten out of the fifteen union republics were sub-divided further into regions that also enjoyed the appearance of some sovereignty, although significantly less than that of the 
union republics. Four of these union republics wer: divided in part along ethnic lines. The creation of autonomous republics (ethnic territories within the Union republics), like the creation of the Soviet republics, was intended as an instrument of consolidation to crush separatism. $^{48}$ The policy turned out to have many serious drawbacks. Minorities that were not granted their own autonomous republics were resentful. Quotas that favored titular nationalities in republican adrninistrations resulted in the rise of "parasitic attitudes and the diminishing prestige of productive work." ${ }^{49}$ National groups living in ministates with their own political infrastructures have been the most effective lobbyists for regional autonomy and, in the case of Tatarstan and Chechenya, independence from the RF. Not surprisingly, in two of the four union republics with ethnic subdivisions, Azerbaijan and Georgia, civil war has broken out. In a third, Russia, several ethnic groups are in conflict, as this article makes clear. The fourth former Soviet republic that was divided partly on ethnic grounds is Uzbekistan.

Most importantly, the tradition of special privileges for autonomous ethnic republics has greatly complicated the post-Soviet regime's attempts to create a law-based state in Russia. The autonomous republics on average have fewer resources, less industrial wealth, and contribute far less in taxes than the krais and oblasts. ${ }^{50}$ But Soviet policies led the republics to expect to be treated better than the more populous Russian regions. ${ }^{51}$ Even in post-Communist Russia, autonomous republics continue to enjoy far more political and economic autonomy than the ethnic-Russian regions. Krai and oblast leaders' perception that republics are getting an unfair advantage was the major impediment to swift completion of a new constitution during the 1993 Constituent Assembly. ${ }^{52}$

Stalin's second strategy was arbitrarily to combine two or more unrelated ethnic groups within a single ethnic territory--presumably to weaken secessionist aspirations. For example, in what became Karachay-Cherkessia, Stalin combined Caucasians (Cherkess) and 
Turkic (Karachay) peoples whose languages are mutually unintelligible. ${ }^{53}$ A similai policy resulted in a combined Kabardino-Balkarian republic, which inter-ethnic strife is now threatening to dissolve. ${ }^{54}$

Stalin's third strategy was to divide ethnic groups to weaken power blocs with imperiously drawn, artificial borders. In 1937 Stalin created three separate ethnic entities out of the former Mongolian Buryat Autonomous Republic: the republic of Buryatia; the Aga Buryat area within Chita oblast, which contained a significant portion of the former Buryat-Mongolia's cattle and farm areas; and the Ust' Orda area located in Irkutsk oblast, which was rich in lead. ${ }^{55}$ Buryats have been increasingly vocal in their demand that these three parts be reunited. On 3 June 1993, the Buryat parliament declared Stalin's 1937 decision to split up the republic to be unconstitutional. ${ }^{56}$ One Russian official described the situation in Buryatia as potentially as explosive as Nagorno-Karabakh, where Armenians have been agitating for independence from Azerbaijan.

The fourth strategy was deportation. Seven ethnic groups were deported from their native territories en masse: the Volga Germans; the Kalmyks; the Crimean Tatars; and the Chechens, Ingush, Karachai, and Balkars of the Northern Caucasus. Conquest estimates that the total number of people despatched into exile was approximately $1,250,000 .^{57}$ Many thousands of deportees perished en route.

Khrushchev's 1956 edict to allow most of the deported nationalities to return created new problems, which were aggravated by the Law on the Rehabilitation of the Repressed peoples passed by the Supreme Soviet in 1991. This law allowed the deported nationalities to claim their former territories. The conflict over land formerly held by Ingush on the territory of $\mathrm{N}$. Ossetia has become especially fierce. ${ }^{58}$ Russia's apparent pro-Ossetian stance resulted in extraordinarily low support for Yeltsin in Ingushetia in the 25 April 1993 
referendum. ${ }^{59}$ Similar problems have arisen for other deported nationalities, although no other conflict is as violent. ${ }^{60}$

The fifth strategy was to encourage or in some cases to enforce Russian migration to the periphery, not only to the former Soviet republics, but also to regions within the Russian federation. The Soviet government held out the promise of significantly higher salaries as well as tax advantages for citizens willing to relocate, particularly to the Far East. $^{61}$

In summary, the creation of a federal state based on ethnic divisions and protection of national groups' right of self-determination were intended as temporary measures to facilitate central control and to crush separatist aspirations. These and other policies described above have had unintended, surprisingly divisive consequences during the last five years--both in the Soviet Union and in the Russian republic. Interestingly, ethnic problems are most acute in those former Soviet republics that were subdivided in part along ethnic lines, including Azerbaijan, Georgia, and Russia.

\section{PART 3: BORDERS}

Because Russia has no natural boundaries in the West or the South, beliefs about the legitimacy of Russia's borders play an exaggerated role. Paul Goble explains, "Because Russia became an empire before the Russians consolidated as a nation, the psychological limits of the state and of Russian identity have always been problematic. Russia has always been a pre-modern empire with a center and a periphery...."62

The Russian state has never existed within its current borders. Late imperial Russia and the Soviet Union both encompassed a significantly larger territory. Russia originated in what is now Ukraine. Kievan Rus lasted from the 9th through the 13th centuries, when it was conquered by the Tatars, who ruled most of European Russia for the 250 year "Tatar Yoke." ${ }^{163}$ During the Kievan Rus period, Russia developed a uniform religion (Eastern 
Orthodoxy) and a common written language and literature. The idea of a Russia separate from the two other Eastern Slavic republics (Ukraine and Belarus) is galling to ethnic Russians. ${ }^{64}$

The next Russian state, which was centered on Moscow, expanded in three directions. ${ }^{65}$ Finnish tribes in what is now Northern Russia were absorbed by Kievan Rus in the 12th century, and by Muscovite Russia in the 16th century. Expansion into the predominantly Muslim South took over three centuries. Ivan the Terrible conquered Islamic Khanates in the Volga Region in the mid-16th century. Many of the regions on and between the Black and Caspian Seas were annexed in the 18th and early 19th century, but Chechenya and Circassia in the Northern Caucasus were not defeated until the late 19th century. ${ }^{66}$ Siberia was conquered beginning in the late 16 th century, but colonization did not really begin until the late 19 th century, largely by convicts.

The Eastern Slavic states of Ukraine and Belarus are arguably more Russian than much of what is now the RF: most of the territory east of Suzdal and south of Kiev was acquired by conquest in later centuries. Ethnic Russians consider themselves to be closer psychologically and culturally (as well as linguistically and geographically) even to the Western Slavs (Czechs and Poles) and Southern Slavs (Serbs, Croats, and Bulgarians) than to the aboriginal peoples of Siberia and the Caucasus.

In a widely distributed brochure published in two Russian newspapers shortly after the RSFSR declared sovereignty, Nobel Laureate Aleksandr Solzhenitsyn recommended the formation of a Pan-Russian Union, which would include Northern Kazakhstan (heavily populated by Russians); and those parts of the Ukraine and Belarus that chose to remain with their Russian brethren. ${ }^{67}$ This proposal was in keeping with the 19th century Slavophile movement, which Solzhenitsyn and other modern Russian nationalists are trying to revive. Non-Russian areas of the RF with external borders (such as Buryatia, Tuva, and 
the Northern Caucasus) would be free to secede from the RF if the majority of the republic so chose. Those non-ethnic Russian republics with no borders external to the RF, such as Tatarstan, would have to remain part of Russia, but their economic, religious, and ethnic needs would have to receive utmost attention, Solzhenitsyn argued. Since then, a number of Russian nationalist parties developed proposals for a Russian Federation with redrawn borders, many of which include Ukraine or parts of it. ${ }^{68}$

A poll commissioned by Yeltsin's government in 1993 indicates that many Russians are dissatisfied with Russia's current borders, and moreover, that ethnic Russians and nonethnic Russian citizens of Russia have conflicting views about where the borders should be. Thirty-nine percent of those polled in one ethnic-Russian region claimed that the Russian state should encompass the whole territory of the former Soviet Union. In the non-Russian ethnic republics, an average of forty percent of those polled claimed that either Russia's present borders were too big, or that the question was too difficult to answer. ${ }^{69}$

Borders are increasingly porous to trade, sometimes outside of Moscow's control. Economic associations and free-trade zones are forming both among Russian Federation regions and between the regions and other countries. There are at least eight separate economic associations to which RF subjects belong: North West Association; Central Russian Association of oblasts and cities; Central Black Earth Region Association of oblasts; Greater Volga Association; Greater Ural Association: Siberian Accord; Far Eastern Economic Association; and the Association of Autonomous Okrugs. ${ }^{70}$

Three factors make trade between the Russian Far East and its neighbors especially attractive: the enormous distance between Moscow and Eastern Siberia, the booming economies of the Pacific Rim region, and resource complementarities. Russia has a comparative economic advantage in wood, minerals, oil, and other natural resources, while Japan and South Korea excel in technology. One proposed project to process raw materials 
will draw on North Korean and Chinese labor, South Korean and Japanese technologies, and Russian natural resources. ${ }^{71}$ Russian fishing vessels are selling fish directly to Japan, rather than arranging trade through official channels. ${ }^{72}$ Cross border trade is also flourishing between Karelia and Finland and among countries near the Black and Caspian seas. $^{73}$

The regions' economic interests do not necessarily coincide with Moscow's political interests, however. Yeltsin's government opposed a Vladivostok initiative jointly to develop heavy industry with Pacific Rim countries, and to create a free economic zone. Moltz attributes Moscow's opposition to this project to its fear that transborder regional integration may lead to national disintegration. ${ }^{74}$

The most alarming aspect of Moscow's declining control over regional exports is the possibility that nuclear materials or expertise would be sold, for example, to North Korea or Iran. So far, none of the numerous allegations of nuclear smuggling has been publicly confirmed by a Western government agency. ${ }^{75}$ But there appear to have been several cases in which government officials were able to impede what might otherwise have been a dangerous situation. In December 1992, for example, the Russian government caught 36 nuclear scientists on a plane bound for North Korea. ${ }^{76}$ Disgruntled nuclear weapons scientists's threatened strikes at the design laboratories Arzamas 16 and Chelyabinsk 70 is yet another indication of the kind of dangers likely to emerge if Moscow declines to keep take the scientists' needs more seriously. ${ }^{77}$

\section{PAR'T 4: WEAKENED CENTRAL CONTROL AND LACK OF ORDER}

Galina Starovoiteva, former advisor to Boris Yeltsin on nationality issues, claims that "the unity of any state is dependent on two basic factors: an integrated economic system (market or command) and a uniform ideological system, whether political, nationalist, or religious." Both, she claims, were destroyed with the Soviet Union. ${ }^{78}$ The KGB and the 
party were the principal unifying forces of the Communist regime; no other unifying force has taken their place. This, together with the incessant fighting between the executive and legislative branches has created not only a power vacuum, but also a sort of "glue vacuum." Very little is left to hold the country together.

In a society characterized by order, citizens have the following expectations: property relationships will be stable, promises will be kept, and individuals will be secure against violence. ${ }^{79}$ Instead, the crime rate in Russia is widely perceived to be soaring. ${ }^{80}$ This, together with the Central Bank's sudden announcement in July 1993 that it was withdrawing from circulation all rubles printed before that year, may have dealt a fatal blow to Russian citizens' faith in their currency and their confidence in the government's ahility to protect private property. ${ }^{81}$

Some order-creating entities were destroyed with the end of the Communist regime. Those that still exist are often in conflict. Federal bureaucracies are now competing, rather than cooperating, particularly in setting economic policy. Failure to develop a coherent economic policy is frightening off investors. ${ }^{82}$ Foreign firms demand, at a minimum, that the government know the law and guarantee the law's continuity. Multilateral lending agencies demand that governments account for assistance provided. ${ }^{83}$ The Russian government has been unable to provide these assurances, which has adversely affected its ability to attract investors and foreign assistance. Strife between the young reformers hired by Yegor Gaidar, and the older conservatives brought on by Victor Chernomyrdin, has played out in a series of disastrous economic policies approved in July 1993 that would lead, if implemented, to a budget deficit equal to $25 \%$ of Russia's GDP. ${ }^{\text {B4 }}$ U.S. government officials also lament the lack of a coherent policy on implementing export controls, and the difficultly of determining the responsible agencies. It is not just that agencies don't agree about how to interpret policies, but that the chain of command is unclear. 
One prescient analyst noted shortly after the failed coup in 1991, "Modern states rest less on palpable things, like building and tanks, than on habits of obedience and accountability that link higher and lower of ficials in a government organized by laws and rules, and on the political culture that supports these laws and rules.... What the coup made manifest was a growing disintegration of the state." ${ }^{\text {8s }}$ The conflict among governing bodies-- especially between the executive and parliamentary branches--has created a climate of chaos, which is now being mirrored in some of the regions. Chechenya's radical nationalist president, Dudaev, ousted the parliament in April 1993; that republic is now close to civil war. ${ }^{86}$ Kalmykia's reformist president llyumzhinov disbanded the parliament and vowed to replace it with a much smaller, more "professional" body. ${ }^{87}$ Yeltsin did not oppose Ilyumzhinov's actions, although they were in clear violation of the RF constitution. ${ }^{88}$ In Mordova, the conservative parliament ousted President Guslyannikov, and ignored Yeltsin's demands that the president be reinstated. ${ }^{89}$ The main issue at stake both in Mordova and Kalmykia is the pace of economic reform: both presidents favor quicker reforms, while the Parliaments are more conservative. The disregard of RF laws in all three republics illustrates the confusion over which law takes precedence: that of the center or that of the constituent republics.

Perhaps most importantly, chaos in Moscow has allowed regional leaders and nationalist organizations to wrest more power for themselves. At least twenty constitutions exist in the RF today: the amended 1977 Russian constitution, which is still the only federal constitution in force; Yeltsin's July 1993 constitution, the fate of which is not yet determined; and at least eighteen draft constitutions ready for ratification by the parliaments of the republics that signed the Federal Treaty of March $1992 .{ }^{40}$ The leaders of a number of republics made clear at parliamentary hearings in March 1993 that they regarded the Federal Treaty as a step toward confederal relations with Moscow, but they believed that a 
"civilized divorce" will be the final result. ${ }^{91}$ The constitutions of at least nine republics-including Bashkortostan, Buryatia, Chechenya, Kalmykia, Karelia, Mordova, Sakha, Tatarstan, and Tuva--declare primacy of local laws over federal ones. The regions have adopted 14,000 laws that directly contradict federal legislation, none of which has been repealed. ${ }^{92}$ Chechenya has effectively seceded from the Russian Federation. Militant nationalist organizations in several republics have created parallel parliaments or national assemblies. $^{93}$ Two republics--North Ossetia and Ingushetia--unilaterally repealed the central government's decree on disarming unlawful armed groups. ${ }^{94}$ Five republics-Tatarstan, Bashkortostan, Sakha, Chechenya, and Karelia--have demanded the right to float their own currencies and to collect their own taxes. ${ }^{95}$ Krasnoyarsk Krai introduced its own currency in July 1992. ${ }^{96}$

A number of republics were able to extract important concessions from Moscow during the Constitutional Assembly, Tatarstan foremost among them. Prime Minister Chernomyrdin granted permission for weapons producers in Tatarstan to export arms outside of Moscow's purview. Analysts worry that the prospects for illegal proliferation of weapons and technologies may increase, especially because Tatarstan already has iridependent control of its exports. ${ }^{97}$

There are now approximately 150 nationality based political organizations in Russia, a Ministry of Internal Affairs official testified in March 1993, some of which are engaged in illegal activities including inciting ethnic strife or establishing their own militia. Nationalist groups in Tatarstan and Bashkortostan have already formed army units. The Confederation of the Peoples of the Caucasus has announced its intention to establish its own army and air-force, including antiaircraft defense systems. ${ }^{98}$

There is growing concern also about RF army's loyalty to the center, and about increasing evidence of corruption and drug addiction. "Local authorities are luring away the 
troop commanders and military district commanders, " a Russian analyst claims. "People in the military realize that it isn't from the center that they're getting their apartments, kindergartens, and food. And therefore, if they have to make a choice, they will carry out the orders of the local authorities." 99

In June 1993 Vice President Aleksandr Rutskoi described the army as being in "disastrous" condition, and accused the High Command and officers of corruption. He also accused Yeltsin of being more interested in buying off the military leadership with promotions than with addressing the army's problems. ${ }^{100}$ Although Rutskoi's charges were undoubtedly made, at least in part, for political purposes, reports of corruption and lack of discipline abound in the Russian press.

The next section discusses an especially volatile regions in somewhat more detail: the Volga-Ural region--focusing on the republic of Tatarstan. This regions was selected for two reasons: independence movements are strong, and there are large numbers of nuclear weapons and nuclear facilities located in the area.

\section{Greater Tatarstan region}

Tatarstan and the surrounding region north of Crimea has been part of Russia since 1552, when Ivan the Terrible conquered the Kazan Khanate. Tatar nationalists now refer to the last 441 years as a period of Russian occupation and exploitation by Russian "newcomers." One Tatar nationalist complains, "I would very much like to say that Russia gave more to the Tatar civilization than prostitution and alcohol abuse, but I can't say this." 101 Fauzia Bairamova, the leader of the Tatar nationalist party Ittifak, is demanding the return of all lands held by the Tatars in the 13th-14th centuries, which she describes as half of Russia's territory. Ittifak demands the predominantly ethnic-Russian provinces of Simbirsk, Saratov, Samara, Astrakhan, and Orenburg; plus the Ufa Plateau, the Western slope of the Urals, and the lands of the Siberian Tatars and Sergach Mishars. ${ }^{102}$ 
At the time of the October revolution, Tatar intellectuals and religious conservatives advocated the formation of a pan-Turkic autonomous republic, which would be called Idel Ural (Volga-Ural), comprising Tatar, Mari, Udmurt, Chuvash, and Bashkir lands. ${ }^{103}$ The Soviet state opposed the idea of an Idel Ural republic. Stalin employed his typical divide and rule tactics to sabotage pan-Turkic enthusiasm and to undermine the Idel Ural idea. He created autonomous republics for the six officially recognized nationalities in the region: Bashkirs, Chuvash, Mari, Mordovans, Tatars, and Udmurts. "The majority of the peoples of the Middle Volga actually benefitted as a result of Soviet anti-Tatarism and anti-PanTurkism, " Ron Wixman explains. ${ }^{104}$

Since 1990, Tatarstan has emerged as one of the two most militant republics of the Russian Federation. (The other is Chechenya.) Tatar nationalists objected to presidential elections taking place on their territory in June 1991, claiming that Yeltsin "may become the president of the RF, but he won't be our president." I0s Tatarstan acquired its own coat of arms, flag, and constitution, and has its own diplomatic representation within RF embassies. $^{106}$ Tatarstan has demanded to join the CIS. ${ }^{107}$ Tatarstan did not sign the 1992 Federal Treaty, ${ }^{108}$ and threatened to boycott the June 1993 Constitutional Assembly unless its "special relationship" with the RF was acknowledged. ${ }^{109}$ Less than a quarter of those eligible to vote participated in the April 1993 referendum. ${ }^{110}$ Only radical nationalists support outright secession from the RF, however, at least so far. Tatarstan's President Shaymieyev still supports "gradual implementation of Tatarstan's state sovereignty" while maintaining union with Russia. "I

Fauzia Bayramova, the above mentioned leader of Ittifak, claims that Tatarstan's future is as an "independent state with all its attributes," ruling out "delegating any prerogatives to Russia, not even defense." 112 Ittifak and other nationalist organizations strongly discouraged soldiers from serving in the CIS (now Russian) armed forces outside 
of the Volga-Urals region. Later, the official Tatarstan parliament passed a resolution prohibiting citizens from serving outside of Tatarstan or the Volga-Urals Military District, except for soldiers serving as border guards. ${ }^{113}$ Desertion and evasion of conscription have become widespread throughout the RF, but reports suggest that this is particularly the case in Tatarstan. ${ }^{1 / 4}$ Both the Ittifak Party in Tatarstan and the Bashkir Urals Movement have established their own combat detachments. ${ }^{115}$

There has also been renewed support for the 1920s idea of a Volga-Urals confederation, although which republics and provinces would be part of such a confederation--if it were to come into being--is unclear. For example, the Tatar Milli Mejlis, the protoparliament of Tatarstan, supported the initiative of national movements in Tatarstan, Chuvash and Mari El to create a Confederation of Peoples of the Volga and Ural Regions. $^{116}$ Ittifak proposed uniting all Turkic peoples in a pan-Turkic State, which would have access to the Black and Caspian Seas through redrawn borders. Bashkortostan and Tatarstan officially informed the RF government about a draft agreement to set up a Volga-Ural presidential republic with its own legislature. The capital would be Ufa (capital of Bashkortostan), and it would comprise Tatarstan, Bashkortostan, Komi, Udmurtia and Chuvash. ${ }^{117}$

Tatars are spread throughout the region and elsewhere in the Russian Federation. Of the Tatar population of the countries of the former Soviet Union, only $26.5 \%$ live in Tatarstan. An additional 20\% live in the surrounding republics of Bashkortostan, Chuvash. Mordova and Udmurtia. Tatars comprise only $49 \%$ of the population of Tatarstan; Russians comprise $43 \%$, and the remainder are other Turkic and Finno-Ugric peoples, predominantly Chuvash. Tatars outnumber Bashkirs in Bashkortostan. ${ }^{118}$

Half the Volga republics are populated principally by Turkic peoples (Bashkortostan, Chuvash, Tatarstan) and half are populated by Finno-Ugric animist/shamanists and 
Christians (Mari El, Mordova, Udmurtia). Although historically the other five republics resented Tatar economic and cultural domination, these republics now resent Russian economic domination even more. ${ }^{119}$ One Russian journalist warned that actions taken by the Russian government to weaken the separatist movements could lead to the creation of a "bristling enclave" in the center of the RF, bringing ultraradical Turkic nationalists to power throughout the region. ${ }^{120}$

\section{Security Implications of Tatar Separatism}

To understand why Tatar separatism, and especially the revived Idel Ural movement, are so threatening, one must appreciate the kind of assets that exist in the region. First, nuclear weapons design laboratories, nuclear weapons sites, and many manufacturing facilities related to nuclear weapons are located in the republics and oblasts of the VolgaUrals Region. The renowned weapons laboratory Arzamas 16 is located partly on the territory of Mordova and partly in Nizhny Novgorod, and Chelyabinsk 70 is located in the near by province of Chelyabinsk. ${ }^{121}$ Mobile ICBMs are based in Mari El, Krasnoyarsk, and Perm; silo-based ICBMs are located in Orenburg, Saratov, and Chelyabinsk. ${ }^{122}$ Uranium is enriched in Krasnoyarsk and Sverdlovsk, and reprocessing facilities are located in Chelyabinsk and Krasnoyarsk. ${ }^{123}$ Ballistic missiles or bombers are produced in Samara and Udmurtia. ${ }^{124} 80 \%$ of Mari El's industry is defense-related. ${ }^{125}$ Udmurtia manufactures rockets, communication facilities and accessories for nuclear weapons. Chemical weapons, principally lewisite (a blistering agent) are also stored there. ${ }^{126}$

Second, Tatarstan is at the crossroads of major rail and oil and gas pipe lines which link European Russia with Siberia and the Far East. The Volga River, which runs through the proposed Idel-Ural republic, is an important shipping link.

Third, Tatarstan and Bashkortostan, along with many of the surrounding provinces, are tremendously rich in natural resources and industrial capacity. Although seventy-five 
percent of Russia's oil is found in two autonomous areas in the Tyumen region, most of the remainder is located in these two republics. Bashkortostan has on its territory as much oil as Kuwait. Large coal and copper deposits were recently discovered in Tatarstan. ${ }^{127}$ Tatarstan's GNP exceeds that of Armenia, Estonia, Latvia, Lithuania, Moldova, Tajikistan, and Turkmenistan. Most of Russia's gasoline refining capacity is located in the Volga-Ural region. ${ }^{128}$ Tatarstan produces a significant fraction of Russia's trucking fleet as well as Backfire aircraft. ${ }^{129}$ Samara, a predominantly ethnic-Russian province to which radical Tatar nationalists are now laying claim, produced an astonishing $44.8 \%$ of all machinery and equipment exported by the RF in 1991. Most of Russia's Volga automobile manufacturing capacity is located in Samara, as are a number of military enterprises. ${ }^{130}$ Two out of the three regions that contributed the largest fraction of Russia's convertible currency export earnings in 1991 are located in this region: Samara and Krasnoyarsk (Tyumen, where most of Russia's oil is located, is the third.) ${ }^{131}$

Russians who worry about separatist movements in the region take comfort in the knowledge that a Greater Tatarstan, even one that included the neighboring five independence-minded republics, would have no borders external to Russia and would therefore have difficultly surviving as a separate state. ${ }^{132}$ But this problem could be overcome if one or more of the regions south of Bashkortostan were convinced to join an Idel Ural republic. "People here do not rule out the formation of a Volga-Urals Federation that would include six of the Russian Republic's constituent republics, and even the adjacent provinces," a Russian journalist notes. ${ }^{133}$ As mentioned above, nationalist Tatars are demanding the return to Tatar control of some of the provinces bordering Kazakhstan. Were the official parliament to make such demands, conflict could easily turn violent. The population of the regions south and east of Bashkortostan is predominantly ethnic-Russian and "stable" or at worst "potentially unstable," according to a study of 
investment risks recently published by Commersant. ${ }^{134}$ All with the exception of Samara showed relatively strong support for Yeltsin in the April 1993 referendum. $^{135}$ As is the case throughout the RF, the provinces in general are far wealthier than the republics. Sverdlovsk, for example, paid 95 billion rubles in federal taxes in 1992, and received 30 billion back. Most republics, in contrast, contribute far less than they receive. ${ }^{136}$ If resentment over revenue sharing begins to take on ethnic dimensions, as undoubtedly it will, a more likely result than union is precisely the reverse: ethnic-Russians will begin to leave the Turkic republics, and Turkic minorities now living in the neighboring provinces will migrate to Tatarstan, Chuvash or Bashkortostan. ${ }^{137}$

Increased support for Idel-Ural even in the surrounding provinces cannot be entirely ruled out, however, mainly because of economic incentives. Two economic associations have already been formed in the Volga-Ural region that comprise both ethnic-Russian and non-ethnic Russian regions. ${ }^{138}$ Agitation to form stronger political bonds among regions is not confined to the republics. Several democratic organizations in the Urals proposed to the Russian Federation Parliament in 1992 that a Ural republic be formed, comprising Orenburg, Chelyabinsk, Kurgan and Sverdlovsk oblasts. ${ }^{139}$ Most importantly, Sverdlovsk's July 1993 proclamation that it had changed its name and status to the Ural Republic suggests that economic considerations are beginning to dominate nationalist sentiments as well as allegiance to the center. ${ }^{140}$ If this trend were to continue in other provinces, support for a Volga-Ural confederation may grow. Given the enormous economic and military capacity of the Volga-Ural region, violent conflict would be the likely outcome.

\section{CONCLUSION:}

Russia's legitimacy weakens on numerous fronts. Federal and regional leaders compete for citizens' loyalty. Ethnic tensions rise. Power devolves to the regions. 
Republics' laws conflict with federal ones. Republics set their own foreign and economic policies. No external threat counteracts internal centrifugal tensions. Nor can the center count on the armed forces to hold the regions in check. Manning levels for enlisted men will soon preclude the armed forces's normal functioning, and the allegiance of army units is uncertain. Taken together, these factors suggest that Russia is not sustainable as a single state.

In Soviet Russia, order was maintained--not by the rule of law, which was neither uniform nor consistent--but by tyranny. No order-creating entities have yet appeared to take the place of the Communist Party and the KGB. The existence of competing constitutions, together with the Russian public's acquired disdain for the law, make a lawbased state improbable in the near future. The parliament's sudden decision to remove rubles from circulation in July 1993 dealt a crippling blow to citizens' faith in the ability of the government to protect contracts and to maintain a credible currency. Russia is failing to meet the obligations of a sovereign power.

Ironically, early Soviet policies intended to facilitate central control by crushing ethnic-nationalist aspirations laid the foundation for the break-up of the Soviet Union and the possible break-up of three of the four Soviet republics that contain autonomous ethnic republics: Georgia, Azerbaijan, and Russia. The formation of a federal system based on ethnic subdivisions created the expectation and the political infrastructure of national statehood within those republics. In Russia, intense rivalries over scarce resources--both among ethnic republics and between ethnic and non-ethnic regions--could lead to civil war.

The potential fragmentation of Russia poses far graver threats to world security than did the Soviet Union's demise, but once again intelligence analysts and policy makers ignore the facts. Sovereignty grows weaker in Russia--perhaps it is dying; utter chaos threatens to emerge. Ethnic divisiveness and demands for greater independence are acute in 
areas with vast nuclear arsenals that border Kazakhstan, China, Japan, and the Koreas. We cannot afford to continue to ignore Russia's impending collapse; war and peace are at stake.

The following concrete recommendations--addressed to both U.S. and Russian policy makers--follow from the preceding analysis.

The U.S. government needs to take the potential for Russia to fragment far more seriously. Russian break-up will have profound implications for U.S. relations with Russia's neighbors, including the Pacific Rim and the former Soviet republics. Nationalist movements and regional economies should be tracked. Appropriate responses to the sale or capture of nuclear weapons, facilities or materials, and to the appearance of new nuclear states should be considered.

If and when parts of Russia begin to secede, the U.S. adrninistration should not repeat the mistakes the previous administration made with respect to Ukraine. Clinton should take all fledgling secessionist republics seriously, not just those with nuclear weapons or facilities on their territory.

The fight between Yeltsin and the parliament could easily exacerbate center-periphery tensions with each side in this fight tempted to exploit ethnic cleavages as a source of support against the other. Ratcheting up this conflict risks worsening ethnic tensions; the parliament, after all, represents regional interest. The U.S. should avoid demonizing the parliament.

Redeployment or deactivation of weapons located in politically volatile regions should be considered.

Unless all subjects of the federation are given equal economic and political powers, Yeltsin and his successors' efforts to maintain Russia's integrity will fail. At the same time, Yeltsin faces a difficult challenge. Granting oblasts and krais equal powers to those enjoyed by the republics will infuriate the republics, but allowing non-Russians to maintain greater powers will inflame ethnic tensions. Of these two, the former is nonetheless the better strategy. If powers continue to be granted on the basis of ethnicity, ethnic tensions will tear the RF apart.

Most importantly, Yeltsin should not yield to the temptation to take away rights already granted to republics; the other subjects' rights should be brought up to the level of those enjoyed by republics, not the other way around. When Gorbachev tried to reign in the union republics' newly acquired freedorns, the Soviet Union splintered. Yeltsin should learn from Gorbachev's mistakes. 
1.Ann Sheehy, "Deputy Premier Fedorov on Demands of Republics" RFE-RL Daily Report. 3 June 1993.

2.John Lloyd, "Fyodorov Bares All on Russia's Economic Woes" Financial Times 27 May 1993.

3.Erik Whitlock, "Fedorov on Reform, Economy" RFE-RL Daily Report 8 June 1993.

4.John Lloyd, "Fyodorov Bares All on Russia's Economic Woes" Financial Times 27 May 1993. David Wolff has observed Chinese yuan being used as payment as far West as Lake Baikal. Personal communication with David Wolff, July 1993.

5.Sheila Marnie and Albert Motivans, "Rising Crime Rates: Perceptions and Reality" RFERL Research Report 16 April 1993.

6.Lt. Gen. Vladimir Bondartsev, first deputy chief of the Defense Ministry's organization-mobilization directorate, said on 15 July that by Fall 1993, manning levels for enlisted men would reach one third of the required number, making normal functioning of the army impossible. Stephen Foye, "More on Army's Manpower Problems" RFE-RL Daily Report, 16 July 1993.

7.Russian Defense Minister Pavel Grachev explains, "One cannot forget that on the territory of Russia there live some 20 million inhabitants who profess Islam. If the flames of war are not put out in Tadjikistan, then there are possible dangerous consequences even for Russia, all the more so since aggressive inclinations are appearing in Chechenya." Quoted in John Lepingwell, "Restructuring the Russian Military" RFE-RL. Research Report, 4 June 1993. 8.Clay Moltz, "The Russian Economic Crisis: Implications for Asian-Pacific Policy and Security," delivered at the conference "The Asia Pacific Security Region: Links Between Economic and Security Relations," La Jolla, Calif., 13-15 May 1993.

9.John Locke, "Essay Concerning Human Understanding."

10.Thomas Hobbes, Leviathan (London: Basic Blackwell Oxford, 1957), 112. 
11.John Herz explains, "Throughout history, that unit which afforded protection and security to human beings has tended to become the basic political unit; people, in the long run, will recognize that authority, any authority, which possesses the power of protection." John Herz, "Rise and Demise of the Territorial State" World Politics 9, no. 4 (July 1957), 474.

12. Weber attributes a state's legitimacy to tradition (as in the divine right of kings); law; or charismatic leadership. Russia's current problem may be explained in part by the fact that none of these legitimacy-enhancing institutions is at work in the RF today.

13.Georg Simmel, "The Web of Group-Affiliations" in Conflict and the Web of GroupAffiliations translated by Reinhard Bendix (New York: Free Press, 1955), 98-107. See also Charles Tilly, Coercion. Capital and European States, AD 990-1990 (Cambridge: Basil Blackwell, 1990), 67-95; and Michael Howard, "War and the Nation-state" Daedalus 108, no. 4 (Fall 1978), 101-110.

14.For a fascinating discussion of two competing theories about the implication of the end of the Cold War for the persistence of the modern state, see Michael Desch, "War and State Formation; Peace and State Deformation: The End of the Cold War and the Deconstruction of the Modern State," unpublished manuscript, University of California at Riverside, 1993. Desch argues quite convincingly that theories that attribute state unity to threats are far more compelling than those that claim that states will continue in their present form. Peace, he argues, may be the "undoing" of the modern nation-state.

15.H.H. Gerth and C. Wright Mills, From Max Weber: Essays in Sociology (New York: Oxford University Press, 1946), 78.

16.Ernest Gellner, Nations and Nationalism (Ithaca: Cornell University Press, 1983), 4-5. 17.The tribe and the city-state earned the loyalty of their members, but neither was able to amass great power. Empires tend to accumulate power, but not the loyalty of their subjects. 
Robert Gilpin, "The Global Political System" in J. D. B. Miller and R. J. Vincent, Order and Violence (Oxford: Clarendon Press, 1990), 116.

18. Coercion induces loyal behavior but not feelings of loyalty. Chafetz argues that a coercive regime is not legitimate because compliance will deteriorate when coercion is relaxed. See Glenn Chafetz, Gorbachey, Reform, and the Brezhney Doctrine (Westport, Connecticut: Praeger, 1993), 50.

19. Robert Gilpin, "The Global Political System," 118.

20.For a fascinating discussion of the emerging concept of nation as distinct from state in Russia, see Leokadia Drobizheva, "Perestroika and the Ethnic Consciousness of Russians" in Gail Lapidus and Victor Zaslavsky, eds., Erom Union to Commonwealth: Nationalism. and Separatism in the Soviet Renublics (New York: Cambridge University Press, 1992), 9899.

21."A state is a legal organization, based on a hierarchy of officials. A nation is a community of people who believe themselves to share a cultural heritage." Hugh Seton Watson, "Russian Nationalism in Historical Perspective" in Robert Conquest, ed., The Last Empire: Nationality and the Soviet Future (Stanford: Hoover Institution Press, 1986), 14. See also Gellner, 7; and Anthony D. Smith, "Ethnic Making and Territorial Nationalism" in Alexander Motyl. Thinking Theoretically About Soviet Nationalities (New York: Columbia University Press, 1992), 50.

22. The definition of nation is of course deeply political. Quebecois define nation in terms of language: Canadians in terms of geography and economic efficiency; Pakistanis in terms of religion; and Indians in terms of history and geography.

23.Joseph Stalin. "Marxism and the National Question" (New York: International, 1942), 12.

24.Nikita Moiseyev, an advisor to Yeltsin claims, "The most awful thing is that few are 
aware that we do not have a state yet. There is not even consensus on whether Russia will be a state based on territory, like the United States, or a nation of ethnic "nations," like the former Yugoslavia."

25.Ernst Haas, "What is Nationalism and Why Should We Study It?" International

Qreanization 40, no. 3 (Summer 1986), 710.

26.Pierre Hassner, "Beyond Nationalism and Internationalism" Survival 35, no. 2 (Summer 1993), 50.

27.The preceding paragraph is based on: John Plamenatz, "Two Types of Nationalism" in E. K.emenka, ed., Nationalism. The Nature of an Idea (Canberra: The Australian National University Press, 1973), 22-37; Jack Snyder, "Nationalism and the Crisis of the Post-Soviet State" Survival 35, no. 1 (Spring 1993): 5-26; Pierre Hassner. "Beyond Nationalism and Internationalism" Survival 35, no. 2 (Summer 1993); Anthony D. Smith, "Ethnic Making and Territorial Nationalism" in Alexander Motyl. Thinkino. Theoretically About Soviat Nationalities (New York: Columbia University Press, 1992), 61.

28.David Welsh. "Domestic Politics and Ethnic Conflict" Survival 35, no. I (Spring 1993). 66.

29. Exceptions include Chuvash, who are Christian, and Tuvans, who are predominantly Buddhist.

30.Ann Sheehy, "Russia's Republics: A Threat to Its Territorial Integrity?" REL-RL Research Report 10 May 1993.

31.Pierre Hassner, "Beyond Nationalism and Internationalism" Survival 25, no. 2 (Summer 1993), 51.

32.Jack Snyder, "Nationalism and the Crisis of the Post-Soviet State" Survival 35, no. 1, 12. Snyder, curiously, considers only Russian ethnic nationalism, and entirely ignores the nonRussian nationalities of the RF. 
33.Jack Snyder, "Nationalism and the Crisis of the Post-Soviet State," 12.

34.The nationalist themes emerging in the former Soviet Union are "familiar to specialists in ethnic relations," one such specialist explains. In ethnically mixed areas one expects to see a desire to control ones own territory. In developed regions, one anticipates aspirations to readjust revenue sharing. Although this specialist was referring to the former Soviet Union, the same themes have emerged in Russia. Donald D. Horowitz, "Soviet Ethnic Problems" in Alexander Motyl. Thinking Theoretically Aboul Sovies Nationalities (New York: Columbia University Press. 1992), 14.

35. See Jack Snyder, "Nationalism and the Crisis of the Post-Soviet State," 5-26.

36.N.G. Volkova and L.I. Lavrov. "Sovremennye etnicheskie protsessy." 330. Cited in Jane Ormrod. "The North Caucasus: Fragmentation or Federation'?" in lan Bremmer and Ray Taras, eds., Nations and Politics in the Sovies Successor States (New York: Cambridge University Press. 1993), 451. Paul Goble explains that In 1921.1922, when Stalin forced ethnic groups to identify themselves, they answered "human being" in their native language. Approximately 70 percent of the names of the 400 ethnic groups listed in the 1989 Soviet census mean "human being" in the relevant language. Paul Goble, "CIS, Boom, Bah: The Commonwealth of Independent States and the Post-Soviet Successor States," Speech at the Miller Center. 4 November 1992.

37.1 refer in this paragraph to the type of ethnic nationalism that has recently emerged in Russia. Ciail Fondahl. "Siberia: Native Peoples and Newcomers in Collision" in lan Bremmer and Ray Taras. eds. Nations and Politics in the Soviet Successor States (New York: Cambridge University Press. 1993).

For a discussion of 19th century Russian policies that strengthened ethnic identity among other groups, see Anthony D. Smith. "Ethnic Identity and Territorial Nationalism" in 
Alexander Motyl, Thinking Theoretically About Soviet Nationalities (New York: Columbia University Press, 1992), 56.

38. See for example, Paul Brass, "Language and National Identity in the Soviet Union and India" in Alexander Motyl, Thinkins Theoretically About Soviet Nationalities (New York: Columbia University Press, 1992); and Dru Gladney, Muslim Chinese:Ethnic Nationalism in the People's Republic of China (Harvard University Press, 1991).

39.See Richard Pipes, The Formation of the Soviet Union (Cambridge: Harvard University Press, 1954); and Victor Zaslavsky, "Success and Collapse: Traditional Soviet Nationality Policy" in lan Bremmer and Ray Taras, eds., Nations and Politics in the Soviet Successor States (New York: Cambridge University Press, 1993).

40.Lenin engaged in long arguments (in print) with his contemporaries about how to interpret the vague expression "right of self-determination," especially with Rosa Luxembourg. See V. I. Lenin. Questions of National Policy and Proletarian Internationalism (Moscow: Progress Publisher [no year]). 41.On the language question, see Lenin. 20. "If, in our political agitation, we fail to advance and advocate the slogan of the right to secession, we shall play into the hands, not only of the bourgeoisie, but also of the feudal landlords and the absolutism of the oppressor nation (i.e., the "Great Russians.") l.enin, p.69. Lenin did promote bilingualism. however. On the right of secession: "However meager the Russian Social-Democratic literature on the "right of nations to self-determination" may be, it nevertheless shows clearly that this right has always been understood to mean the right to secession." Lenin. 104. For a description of the development of Stalin's position (in opposition to Bukharin's) see Isaac Deutscher. Stalin: A Political Biography (New York: Oxford University Press, 1967). For discussion of post-Lenin Russification, see John Dunlop, "Language, Culture and Religion" in Robert 
Conquest, ed., The Last Empire: Nationality and the Soviet Euture (Stanford: Hoover

Institution Press, 1986), 266-272.

42.Joseph Stalin, Sochinenive vol. IV, 31-32. Cited in Isaac Deutscher, Stalini_A Political Biography 185.

Finland, Latvia, Lithuania. and White Russiu (Belarus) declared independence from the Soviet Union in 1917. Estonia, the Ukraine, Poland, and the Transcuucasian Federation (later dissolved into Azerbaijan, Georgia, and Armenia) followed in 1918. Of these, only Finland, and to a lesser extent Poland and the Baltic states were successful--the Baltics only until 1940.

Nicholas V. Riasanovsky, A History of Russia Sth ed. (New York: Oxford University Press. 1993), 484, 516.

43.See especially Walter A. Kolarz, "'Bussin and Her Coloniess (New York: Frederick A. Praeger, 1952); Samad Shaheen. The Communist Theory of National Self-Determination. (The Hague: W. Van Hoeve, 1956); Gail Lapidus, ed., The "Nationality" Question in the Soviat Union (New York: Garland Publishing Company, 1992): and lan Bremmer and Ray Taras, eds., Nations and Politics in the Soviel Successor States (New York: Cambridge University Press, 1993).

44.Lenin initially opposed organizing the Soviet state on the federalist principle. MarxistLeninist doctrine holds that not only national differences, but the state itself will eventually wither away.

45.Lenin, 193.

46.See for example Victor Zaslavsky, "Success and Collapse: Traditional Soviet Nationality Policy" in Ian Bremmer and Ray Taras, Nations and Polities in the Soviet Successor States (New York: Cambridge University Press, 1993), 29-42.

47.Ronald Suny, "Roots of the National Question" in Gail Lapidus and Victor Zaslavsky, 
eds., Erom Union Te Commonwealth (New York: Cambridge University Press, 1992), 29. Paul R. Brass, "Language and National Identity: Soviet Union and India" in Alexander Motyl. Thinkine Theoretically About Soviet Nationalities (New York: Columbia University Press, 1992), 113.

48. Richard Pipes, The Formation of the Soviet Union (Cambridge: Harvard University Press, 1954), 247.

49. Victor Zaslavsky, "Success and Collapse: Traditional Soviet Nationality Policy" in Ian Bremmer and Ray Taras, Nations and Politics in the Soviet Successor States (New York: Cambridge University Press, 1993), 39.

50.Rolf J. Lanhammer, Matthew J. Sagers and Matthias Lucke, "Regional Distribution of the Russian Federation's Export Earnings Outside the Former Soviet Union and its Implications for Regional Economic Autonomy" Pest-Soviet Geography 33, no. 10 (1992): 617.634 .

51.For more on this point, see Paul Goble, "Russian Break-Up" NEFTE Compass 2, no. 2 (15 January 1993): 10-12.

52.Two predominantly ethnic- Russian, relatively wealthy regions--Sverdlovsk oblast and Primorski krai--proclaimed themselves republics during the Constitutional Assembly in summer 1993. This is particularly surprising in the case of Sverdlovsk because of that oblast's consistent support for Yeltsin--who is from Sverdlovsk. James P. Gallagher, "Regional Discord Rips Russian Unity" Chicago Tribune, 27 June 1993. Ann Sheehy, "Rights of Subjects of Federation Recognized?" RFE-RL Daily Report. 17 June 1993; and Ann Sheehy, "Sverdlovsk Oblast Declares Itself Ural Republic" RFE-RL Daily Report, 2 July 1993.

53.For a more detailed discussion, see Richard Conquest, Soviet Deportation of Nationalities, 24. 
54.A Congress of Balkar People held in January 1992 adopted a resolution proclaiming a separate Balkar Republic; ninety-five percent of Balkars polled supported a separate Balkar Republic within the RF. V. Borisov, "The Number of Legal Entities Has Increased" Sovetskaya Rossiva 21 January 1992, p. 2; cited in FBIS-USR-92-009, 30 January 1992, 111. The Kabardino-Balkar parliament approved the restoration of a Kabardin Republic on its historical territory in February 1992. Dispute about how to divide the territory is delaying implementation of the plan. Igor Terekhov, "The Supreme Soviet Approved the 'Divorce' of Two Peoples," Nezavisimaya Gazeta 15 February 1992, p. 3. Printed in FBISUSR-92-030, 18 March 1992, 70; Alexander Aleshkin, "Is 'Divorce' Inevitable in Kabardino-Balkaria?" Rossiskaya Gazeta 23 May 1992, p. 2. Printed in FBIS-USR-92-073, 53.

55. Goble points out that this policy was necessary because of the location of the Far East Militaiy District in Chita oblast.

56.Ann Sheehy, "Buryat Parliament Declares Splitting Up of Republic in 1937 Unconstitutional" RFE-RL Daily Report 4 June 1993.

57. Conquest, 54.

58.See Ann Sheehy, "Russian Troops Placed on Alert in North Ossetia and Ingushetia" RFE-RL Daily Report, 21 June 1993.

$59.2 .3 \%$ of Ingush voters supported Yeltsin. For Galina Starovoitova's claim that Russia had sided with Ingushetia, see RFE-RL Weekly Review, 11-17 November, 1992. For referendum results, see Philip Smucker, "Russia; Regions Voted for More Autonomy From Moscow" Financial Times, 27 April 1993, 27. Ingushetia also threatened not to attend the Constitutional Assembly unless Yeltsin guaranteed that Ingush refugees could return to their homes in N. Ossetia. Ann Sheehy, "Ingush President May Not Attend Constitutional Assembly" RFE-RL News Briefs 3 June 1993. 
60.See Vera Tolz, "Russia's Kalmyk Republic Follows Its Own Course" $\underline{\text { REE-RL Research }}$ Report, 21 May 1993.

61.For a discussion of Soviet colonization of the Far East, see Walter Kolarz, The Peoples of the Soviet Far East (New York: Frederick A. Praeger), 1954.

62.Paul Goble, "Russian Break-Up" NEFTE Compass 2, no. 2 (15 January 1993), 11.

63.Nicholas V. Riasanovsky, A History of Russia 5th ed. (New York: Oxford University Press, 1993), 23-60; 67-87. Riasanovsky dates Kievan Rus from 882 to 1240.

64.For a fascinating discussion of the birth of the Ukrainian state (as distinct from Russia), see Anthony D. Smith, "Ethnic Identity and Territorial Nationalism" in Alexander Motyl, Thinking Theoretically About Soviet Nationalities (New York: Columbia University Press, 1992), 48.

65.The Muscovite state displayed a marked proclivity for expansion. The Muscovite kingdom began with 430,000 square kilometers in 1480 , and acquired an average of 35,000 square kilometers per year in the succeeding 150 years. Richard Pipes, Russia Under the Old Regime (New York: Scribners, 1974), 83.

66.Nicholas V. Riasanovsky, A History of Russia 5th ed. (New York: Oxford University Press, 1993); Robert Conquest, The Soviet Deportation of Nationalities (New York: St. Martin's Press, 1960); Walter Kolarz, The Peoples of the Soviet Far East (New York: Frederick A. Praeger, 1954).

67.Aleksandr Solzhenitsyn, "How Shall We Reconstitute Russia?" Literaturnaya Gazeta, 18 September 1990. Cited and analyzed in John Dunlop "Russia: Confronting a Loss of Empire" in Ian Bremmer and Ray Taras, eds., Nations and Politics of the Soviet Successor $\underline{\text { States }}$ (New York: Cambridge University Press, 1993) and John Dunlop, "Solzhenitsyn Calls for the Dismemberment of the Soviet Union," Report on the USSR 14 December 1990, 3-4. 
68.See for example, V. Lvova, "Who Will Protect the Russians?" Express Chronicle 307, no. 25, 25 June 1993.

69.Rowland Evans and Robert Novak, "Yeltsin's Challenge" Washington Post 26 April 1993.

70.N. V. Petrov, S. S. Mixeev, and L. V. Smirnyagin, "Situatsia v Regionax na 12/1/92," (unpublished manuscript) Moscow: Center for Political-Geographical Research, 1992. 71.See Clay Moltz, "Panel on Patterns of Disintegration in the Former USSR" Post-Soviet Geography XXXIII, no. 6, p. 370. Citing Far Eastern Economic Review January 16, 1992. 72.Georgi Vachnadze, Goryachiye Tochki Rossii (Marburg, Germany: Blaue Horner Verlag, 1993), 78.

73.Clay Moltz, in "Panel on Patterns of Disintegration in the Former USSR" Post-Soviet Geography XXXIII, no. 6, p. 369.

74.Clay Moltz, in "Panel on Patterns of Disintegration in the Former USSR" Post-Soviet Geography XXXIII, no. 6, p. 370.

75.See generally Eye on Supply, Emerging Nuclear Suppliers Project, Monterey Institute of International Studies.

76. William C. Potter, "Nuclear Exports From the Former Soviet Union: What's New, What's True," Arms Control Today 23, no. 1 (January/February 1993), 8.

77.Celestine Bohlen, "Amid Nuclear Transition, Russia's Scientific Elite Loses Its Security" New York Times 11 July 1993; Nuclear Weapons Workers Issue Strike Warning" $\underline{\text { RFE/RL }}$ Daily Report, 7 July 1993.

78.Galina Starovoiteva, "Nationality Policies in the Period of Perestroika: Some Comments From a Political Actor" in Gail Lapidus and Victor Zaslavsky, eds., From Union to Commonwealth: Nationalism and Separatism in the Soviet Republics (New York: Cambridge University Press, 1992), 116. 
79.Hedley Bull, The Anarchical Society (New York: Columbia University Press, 1977), 4-5. 80.Sheila Marnie and Albert Motivans, "Rising Crime Rates: Perceptions and Reality" RFERL Research Report no. 16, 16 April 1993.

81."The Rouble Used as a Bomb" Economist 31 July 1993, 41.

82.Peter J. Stavrakis, "The Russian Government's Bureaucracies: Transition or Disintegration?" RFE-RL Research Report, 29 April 1993.

83.Peter J. Stavrakis, "The Russian Government's Bureaucracies: Transition or Disintegration?" RFE-RL Research Report, 29 April 1993.

84."The Rouble Used as a Bomb" Economist 31 July 1993, 41.

85. Charles H. Fairbanks, "After the Moscow Coup" Journal of Democracy 2, no. 4 (Fall 1991), 4.

86.See for example, Timur Muzaev, "Opposition Hides From Dudaev" Express Chronicle 306, no. 24, 18 June 1993.

87.The president bribed the parliament (by offering them interest free loans) to approve bills abolishing all local councils and reducing the parliament's number from 130 to 25 . In order to receive the loans, the parliamentarians had to agree to renounce politics and go into business. RF parliamentarians have hinted that they too might be susceptible to similar bribes, such as Moscow apartments, life-long salaries, and priority booking on trains and planes. "A Foreign Aid Opportunity" Economist 29 May 1993.

88.Vera Tolz, "Russia's Kalmyk Republic Follows Its Own Course" RFE-RL Research Report 21 May 1993.

89.See for example, Ann Sheehy, "Constitutional Court Ruling on Moldova" RFE-RL News Briefs 4 June 1993.

90.Vladimir Yemelyanenko, "The Country Will Collapse" Moscow News 7 February 1993; 
John Lloyd and Dmitri Volkov, "Constitutional Reform a Step Closer in Russia" Financial Times 12 July 1993, 2.

91.Yelena Pestrukhina, "Shakhrai Puts Forth 11 Principles" Megapolis-Express, 3 March 1993, p. 13. Reported in The Current Digest of the Post-Soviet Press XLV, no. 9 (31 March 1993), 11.

92.Paul Goble, "Russia Break-Up" NEFTE Compass 2, no. 2 (15 January 1993), 11. 93.One example is the Tatar Milli Mejlis. Radicals in Tatarstan hope that the parallel parliament will eventually supersede the existing one. Artyom Karapetyan, "Nationalist Passions in Tatarstan" Moscow News 22 January 1992.

94.Vladimir Yemelyanenko, "The Country Will Collapse" Moscow News 7 February 1993. 95.Ann Sheehy, "Deputy Premier Fedorov on Demands of Republics" RFE/RL Daily Report, 4 June 1993.

96. RA Report 14, January 1993, 70.

97."Tatarstan Wins More Independence" Commersant 30 June 1993, 5.

98. Yelena Pestrukhina, "Shakhrai Puts Forth 11 Principles" Megapolis-Express, 3 March 1993, p. 13. Reported in The Current Digest of the Post-Soviet Press XLV, no. 9 (31 March 1993), 11.

99.Lidia Malash, Interview with Anatoly Antonov, Director of the Center for SocioStrategic Research, Magapolis-Express, in Current Digest of the Post-Soviet Press, 17 March 1993.

100.Stephen Foye, "Rutskoi Hits Yeltsin on State of the Army" RFE-RL Daily Report 18 June 1993.

101.Flora Zainullina, second in command of Ittifak. Quoted in Georgi Vachnadze, "Goryachiye Tochkii Rossii," 128.

102.A. Putko, "How It is Being Proposed that the Tatars Free Themselves from the 
'Russian Yoke'" Izvestia 25 November 1991, p.4. Reported in Current Digest of the Soviet Press 25 December 1991.

103.Ron Wixman, "The Middle Volga: Ethnic Archipelago" in lan Bremmer and Ray Taras, Nations and Politics in the Soviet Successor States (New York: Cambridge University Press, 1993), 429.

104.Ron Wixman, "The Middle Volga: Ethnic Archipelago" in lan Bremmer and Ray Taras, Nations and Politics in the Soviet Successor States (New York: Cambridge University Press, 1993), 430.

105.Justin Burke, "Yeltsin Faces Nationalist Protest" Christian Science Monitor 23 April $1991,6$.

106.Carroll Bogert, "Wanting Out of Russia" Newsweek 12 November 1990, 40.

107."Shaymiyev Reiterates Dedication to Union with Russia," Postfactum, 26 January 1992. Reported by British Broadcasting Corporation" 28 January 1992, p. SU/1289/B/1. 108.Viktor Radziyevsky, "Tatarstan, Bashkortostan and the Federation Treaty" Moscow News 6 May 1992.

109.Radik Batyrshin, "Tatars Dissatisfied with Conference" FBIS-SOV-93-121, 25 June $1993,20$.

110.Paul Goble, "Constitutional Splits" NEFTE Compass. v, no. 24 (17 June 1993), 10.

111."Shaymiyev Reiterates Dedication to Union with Russia," Postfactum, 26 January 1992. Reported by British Broadcasting Corporation" 28 January 1992, p. SU/1289/B/1.

112."Tatar Parties Protest at Leadership's Inactivity" Interfax News Agency, Moscow, 18 July 1992. Reported in BBC Summary of World Broadcasts, 20 July 1992, p. SU/1437/B/1. 113.Dmitri Mikhaylin, "Report on Tatarstan Parliament Session Activity" FBIS-USR-92070, 10 June 1992, 51. Originally published in Rossiskaya Gazeta 26 May 1992, 1. 114.N. Morozov, "View From a Region: Tatarstan-- A People's Militia is Being Created" 
Pravda 16 October 1991, pp. 1, 3. Reported in Current Digest of the Soviet Press XLIII, no. 42, p. 28. See also "Tatar Young Men Evade Conscription" BBC Summary of World Broadcasts, 19 August 1992. p. SU/1463/C4/1.

115.Statement by Vyacheslav Ogorodnikov, director of "an administration" of the Ministry of Internal Affairs. Yelena Pestrukhina, "Shakhrai Puts Forth 11 Principles" MegapolisExpress, 3 March 1993, p. 13. Transcribed in The Current Digest of the Post-Soviet Press XLV, no. 9 (31 March 1993), 11.

116."Tatar Calls for Volga-Ural Confederation" RFE-RL Weekly Report, 2 December 1992. 117. Vachnadze, 121 .

118. Bashkirs comprise $22 \%$ of the population of Bashkortostan; Russians $39 \%$; and Tatars 28.4\%. All statistics from Ron Wixman, "The Middle Volga: Ethnic Archipelago" in lan Bremmer and Ray Taras, Nations and Politics in the Soviet Successor States (New York: Cambridge University Press, 1993).

119.Chuvash are predominantly Christian. Bashkirs, like Tatars, are predominantly Muslim. but Wixman notes that shamanism/animism still thrives in Bashkortostan. For a fascinating discussion of the cultures and religions of this region, see Ron Wixman, "The Middle Volga: Ethnic Archipelago" in lan Bremmer and Ray Taras, Nations and Politics in the Soviet Successor States (New York: Cambridge University Press, 1993). 120.Vitaly Portnikov, "Tataria: The Kremlin Under the Crescent" Nezavisimaya Gazeta 26 November 1991. [Reported] in Current Digest of the Soviet Press XLIII, no. 47, 25 December 1991, p. 1 .

121. Vachnadze explains, "Arzamas 16 is still governed by three masters - the land belongs to Mordova, the city council operates under Gorki regional administration, and all industrial sectors depend on the military-industrial complex." Georgi Vachnadze, 110. 122.Robert Norris, "The Nuclear Archipelago" Arms Control Today 22, no. 1 
(January/February 1992), 28-29. Norris lists sites by the names of the towns in which they are located, without naming the republic or oblast.

123. William C. Potter, "Nuclear Profiles of the Soviet Successor States" Monterey Institute of International Studies, April 1993.

124.Robert Norris, "The Nuclear Archipelago" Arms Control Today 22, no. 1

(January/February 1992), 28-29. Norris lists sites by the names of the towns in which they are located, without naming the republic or oblast.

125.Vachnadze, 107.

126. Vachnadze, 111 .

127. Vachnadze, 126.

128.Oil refining takes place at Ryazan and Nizhny Novgorod.

129.Carroll Bogert, "Wanting Out of Russia" Newsweek 12 November 1990, 40.

130. Note that the next biggest exporter of machinery and equipment is the Moscow oblast, which accounts for $12.7 \%$ of Russia's total exports in this sector. Rolf J. Langhammer, Matthew J. Sagers and Matthias Lucke, "Regional Distribution of the Russian Federation's Export Earnings Outside the Former Soviet Union and Its implications for Regional Economic Autonomy" Post-Soviet Geography 33, no. 10 (1992): 617-634.

131. Russia's export earnings are highly concentrated. Most of Russia's wealth is not in the republics, but three out of five republics that contributed from $1 \%$ to $5 \%$ are in the VolgaUrals region. The five are Karelia, Sakha, Bashkortostan, Tatarstan, and Komi. Rolf J. Langhammer, Matthew J. Sagers and Matthias Lucke, "Regional Distribution of the Russian Federation's Export Earnings Outside the Former Soviet Union and Its Implications for Regional Economic Autonomy" Post-Soviet Geography 33, no. 10 (1992), 627.

132. The five neighboring republics include the Turkic republics of Bashkortostan and Chuvash, and the Finnic republics of Udmurtia, Mari El, and Mordova. 
133.Vitaly Portnikov, "Tataria: The Kremlin Under the Crescent" Nezavisimaya Gazeta 26

November 1991. [Reported] in Current Dipest of the Soviet Press XLIII, no. 47, 25

December 1991, p. 1.

134. Tatarstan and Bashkortostan, in contrast, are considered to be "extremely unstable areas." "Russian Investment Risks Mapped" Commersant 28 April, 1993.

135.By support, I mean over $50 \%$ of the voters expressed trust in the president. See "Russian Referendum" Einancial Times 28 April 1993, 2.

136. Ralph Boulton, "Proclamation of Urals Republic Sends Warning to Yeltsin" Reuter Library Report 2 July 1993.

137."The nationalists assign paramount importance not to the rights of the individual but to the rights of the nation, and the migration of Russians out of Tatarstan may begin soon." an ethnic-Russian citizen of Tatarstan complained. Yevgeny Shukin, "Ordinary Ittifak Fascism?" Bessiskaya Gazeta, 28 November 1993, p. 3. Reported in Current Divest of the Soviet Press XLVII, no. 47, (December 25, 1991), p. 5.

138. Members of the Greater Volga (Bolshaya Volga) Economic Association include Astrakhan', Volgograd, Samara (Kubyshev), Saratov, Penza, Simbirsk (Ul'yanovsk) and Nizhniy Novgorod (Gor'kiy) oblasts; and Kalmykia, Tatarstan, Chuvash, and Mordova republics. Members of the Greater Urals (Bolshoi Ural) Economic Association include Kurgan, Orenburg, Perm', Yekaterinburg (Sverdlovsk), Cheyabinsk, and Tyumen oblasts: and Bashkortostan and Udmurtia republics. Source: Jean Radvanyi. "And What if Russia Breaks UP: Toward New Regions Divisions" Post Soviel Geography 33, no. 2 (Feb 1992), 73.

139. Vachnadze, 15.

140.John Lloyd, Russia Begins to Fray At the Edges" Financial Times 9 July 1993, 2. 
